\title{
Vegetation survey of the Khomas Hochland in central-western Namibia: syntaxonomical descriptions
}

\author{
Authors \\ 'Prof. Ben Strohbach (1)

\section{Affiliations} \\ 'Biodiversity Research Centre, \\ Namibia University of Science \\ and Technology, Private Bag \\ 13388, Windhoek, Namibia.

\section{Corresponding Author \\ Prof. Ben Strohbach, e-mail: bstrohbach@nust.na}

\section{Dates} \\ Submitted: 1 July 2020 \\ Accepted: 15 April 2021 \\ Published: 15 July 2021

\section{How to cite this article:} \\ Strohbach, B., 2021, 'Vegetation \\ survey of the Khomas Hochland \\ in central-western Namibia: \\ syntaxonomical descriptions' \\ Bothalia 51(2), a4. http://dx.doi. \\ org/10.38201/btha.abc.v51.i2.4
}

Copyright: (C) 2021. The Authors. Licensee: SANBI. This work is licensed under the Creative Commons Attribution 4.0 International License.
Background: The Great Escarpment of southern Africa takes the form of an extended mountainous highland in central-western Namibia, commonly referred to as the 'Khomas Hochland'. It is regarded as an area of high botanical diversity. Yet only few localised studies on the vegetation composition are available. The Khomas Hochland is formed on the southern part of the Damara Orogen and dominated by metamorphosed sediments. Climatically it forms a transition between the hot desert of the Namib and the slightly cooler hot steppe in the inland.

Objectives: To classify and provide syntaxonomical descriptions of the vegetation of the Khomas Hochland.

Methods: A dataset comprising 1151 relevés and 914 species was compiled from various surveys, mostly collected under, and to the standards of, the umbrella project 'Vegetation Survey of Namibia'. For first classifications, the data set was reduced to a synusial set consisting of trees, shrubs, dwarf shrubs and grasses only.

Results: The classification resulted in four major landscape units, being the Pre-Namib and Escarpment zone, the Khomas Hochland proper, riverine habitats as well as surrounding lowlands. The classification was further refined using Cocktail procedures to produce 30 associations, one with four sub-associations. These are described in this paper.

Conclusion: A classification of synoptic data grouped the associations into five orders and one undefined cluster of associations on specialised desert habitats. Four of these orders correspond to the habitat types identified in the first classification. The fifth order, the Senegalio hereroensis-Tarchonanthoetalia camphorathi, represents high mountains of the central Khomas Hochland, which link biogeographically to the grassland biome in South Africa.

Keywords: Damara Orogen; Great Escarpment; highland savanna; modified TWINSPAN; Namib; phytosociology.

\section{Introduction}

The Great Escarpment is a $\pm 5000 \mathrm{~km}$ long geomorphological feature along the rim of the southern African subcontinent. It is regarded as a zone of high biological diversity, containing numerous Centres of Endemism (Clark et al. 2011). Whereas most of the Great Escarpment forms a narrow divide between the coastal lowlands and the inland plateaux, in central Namibia the Damara Orogen created a mountainous landscape nearly $200 \mathrm{~km}$ wide from west to east. This mountainous landscape is commonly referred to as the Khomas Hochland (or Khomas highlands) (Schneider 2004; Swart \& Marais 2009; Goudie \& Viles 
2014). Giess (1998) broadly describes the vegetation as 'highland savanna', without providing any details on composition or diversity.

Although the Khomas Hochland has been identified as an area of high botanical diversity (Hofmeyr 2004; Craven \& Vorster 2006), only a few localised descriptions of the vegetation of this landscape exists. Of note here are a study by Volk and Leippert (1971) on a few farms southeast of Windhoek, using data from the 1950s and 1960s; an unpublished study by Kellner (1986) focusing on the Daan Viljoen Game Reserve west of Windhoek as well as portions of two farms southwest and east of Windhoek; a preliminary description of the vegetation of the Auas Mountain Range south of Windhoek (Burke \& Wittneben 2007); as well as an account of the vegetation of the Auas-Oanob Conservancy southwest of Windhoek (Strohbach 2017). None of these studies provide a comprehensive overview of the entire landscape. In contrast, a fairly comprehensive description of the adjacent central Namib desert is available (Jürgens et al. 2013).

The Vegetation Survey of Namibia project has been initiated to fill this, and similar data gaps, at a national level (Burke \& Strohbach 2000; Strohbach 2001). The project is aimed at providing data about the resource 'natural vegetation' to allow for sustainable planning and management of this renewable resource (Strohbach 2018). Due to the sheer size of the country, however, a strong emphasis is placed on utilising existing reliable data sources in addition to collecting, over a number of seasons, additional, gap-filling data. At the same time, due to the lack of necessary data density for a detailed study, the result will be at a regional overview level (often referred to as 'reconnaissance level') (Küchler \& Zonneveld 1988; Strohbach 2001). This paper aims to contribute a first formal classification and description at this level of the vegetation found in the Khomas Hochland in central-western Namibia.

\section{Methods}

\section{Study area}

The study area is a block of roughly $31000 \mathrm{~km}^{2}$ in central western Namibia, between the coastal Namib desert lowlands and the inland plateaux (Figure 1). It stretches from the border of the Namib-Naukluft Park in the west to about $17^{\circ} 30^{\prime} \mathrm{E}$, and from the B6 trunk road between Okahandja and Karibib in the north to about the Gaub Valley in the south. Administratively, it covers the western half of the Khomas Region, but also reaches into the Erongo and Otjozondjupa regions of Namibia.

The Khomas Hochland had its origin some 900 Ma ago as a sea between two tectonic plates, the Kalahari- and Congo cratons. Sediments deposited in this sea solidified and were metamorphised during the formation of the Gondwana supercontinent \pm 650 to $450 \mathrm{Ma}$ ago. At that stage, uplift also happened, resulting in the Damara Orogen (Schneider 2004; Swart \& Marais

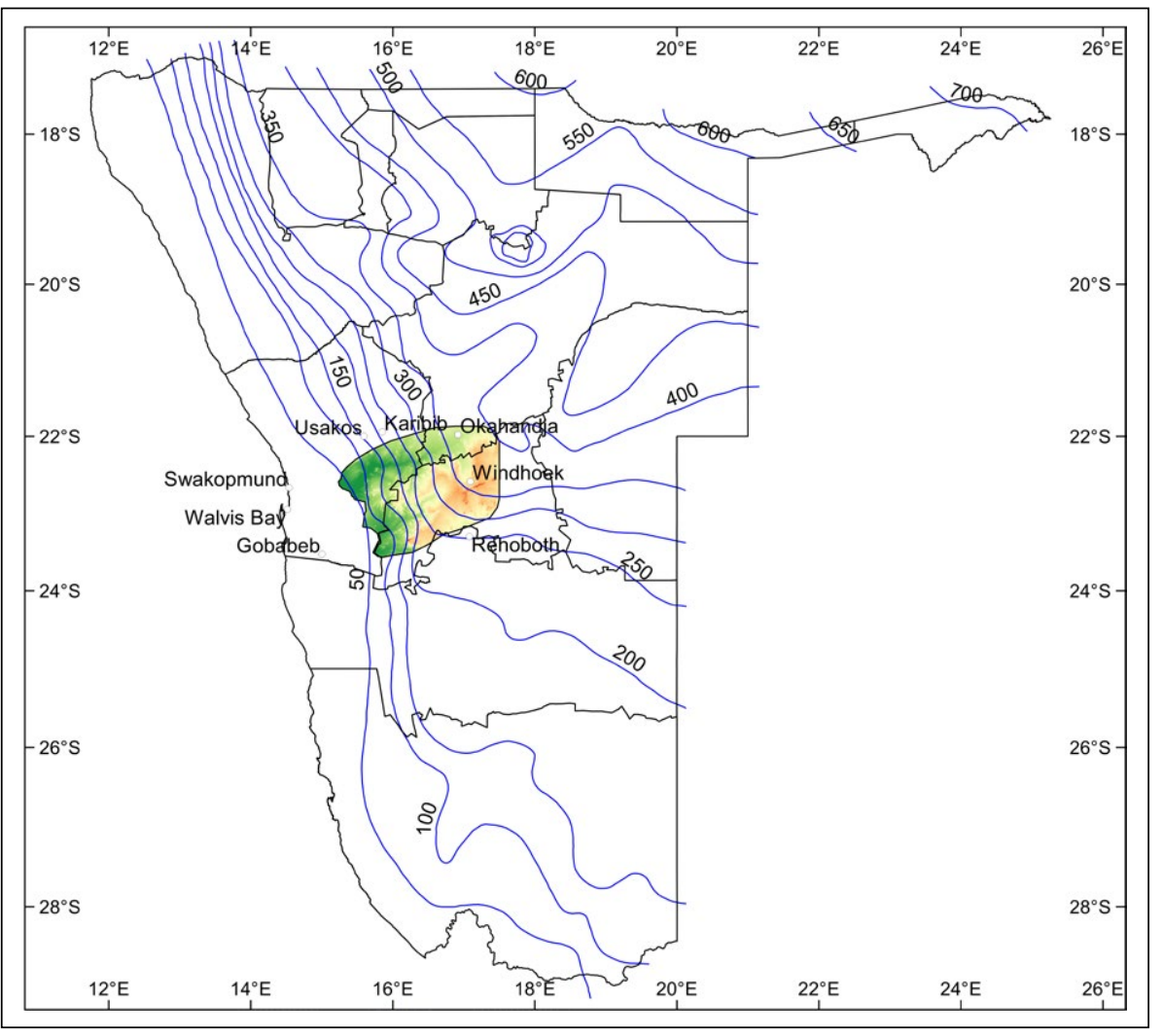

Figure 1. The study area in western central Namibia. Mean Annual Rainfall is indicated as blue isohyets. Data source: NARIS (2001). 


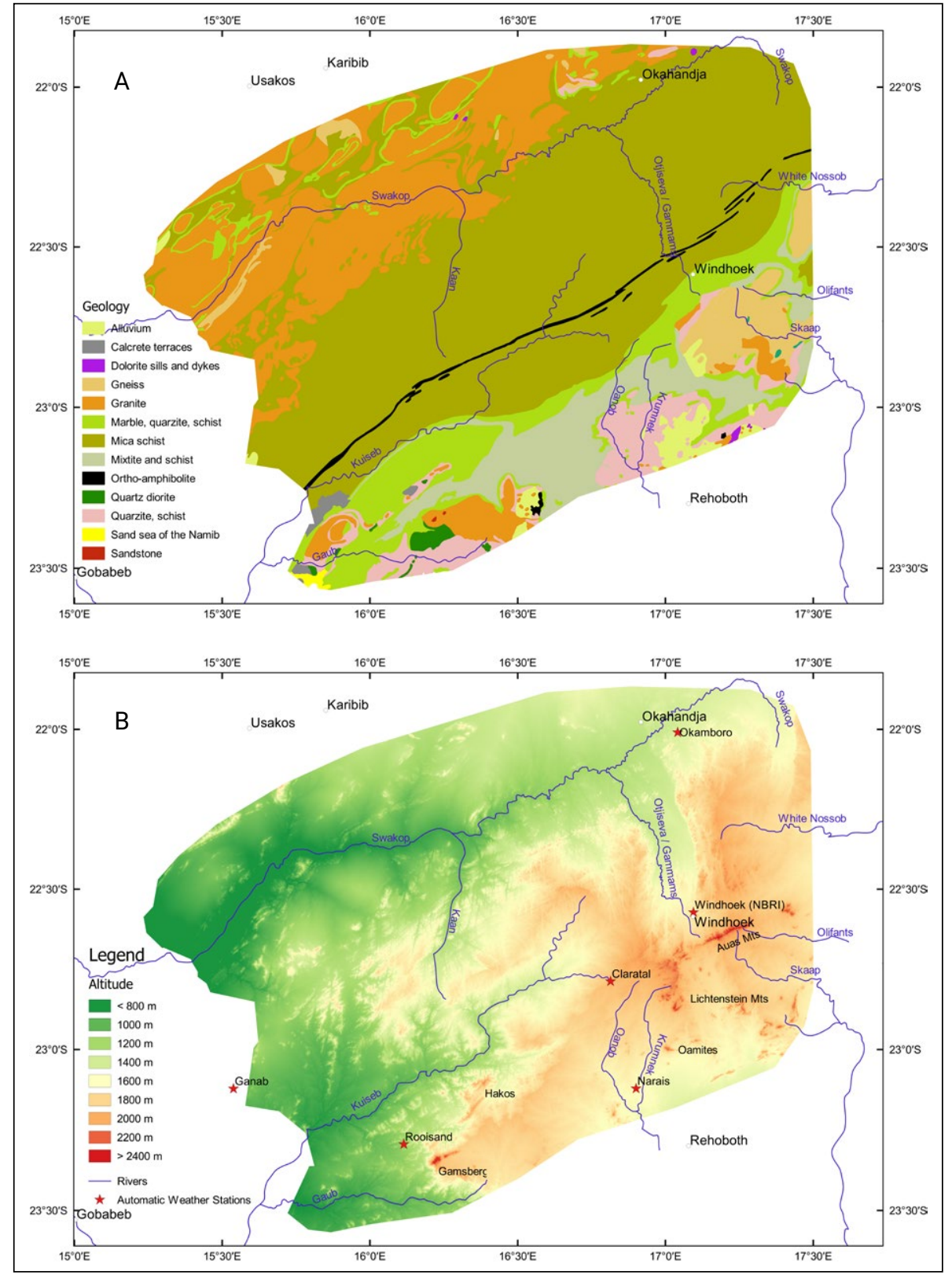

Figure 2. A, Simplified geological map of the study area, indicating the major lithological substrates; B, Topography of the study area, indicating several landmarks and major rivers draining the Khomas Hochland. Data sources: Geological map adapted from Namibia Geological Map (Geological Survey 1980); topography derived from SRTM image (Jarvis et al. 2008).
2009). The main body of the Khomas Hochland consists of mica schists of the Kuiseb and schists and mixtites of the Chuos Formation (Figure 2A). The mica schists of the Kuiseb Formation are dissected by a narrow band of ortho-amphibolites of the Matchless Member. The southern rim is formed by hardened quartzites of the Auas Formation, before merging with older rocks (granites and metamorphites of the Rehoboth Sequence) of the Kalahari Craton. To the north of the Kuiseb formation, intrusive granites resulted also in the formation of several marble ridges (Figure 2A) (Geological Survey 1980; South African Committee for Stratigraphy 1980; Schneider 2004).

The escarpment of the Khomas Hochland raises from the Namib desert plains at about $900 \mathrm{~m}$ above sea level (asl) to well over $1400 \mathrm{~m}$ asl. The central Khomas Hochland forms a deeply dissected, steep mountainous highland, raising to over $2000 \mathrm{~m}$ asl in places (Figure 2B) (Swart \& Marais 2009). This is only topped by the mountain ranges Auas, Lichtenstein, Hakos and Gamsberg, which reach altitudes of over 2400 m asl (Schalk 1983; Swart \& Marais 2009). The study area is drained through a dense system of ephemeral rivers, forming tributaries to the Swakop and Kuiseb rivers to the west, Oanaob and Skaap rivers to the southeast, and White Nossob as well as Olifants rivers to the east (Figure 2b) (Strohbach 2008).

The climate can be described as a hot desert in the western half to a hot steppe in the eastern half, following Köppen (1936). The mean annual precipitation (MAP) ranges from $\pm 50 \mathrm{~mm}$ in the west to about $350 \mathrm{~mm}$ in the east (Figures 1 and 3), with a high degree of variation between seasons. Along the western edge of the study area, the coefficient of variation (CV) 


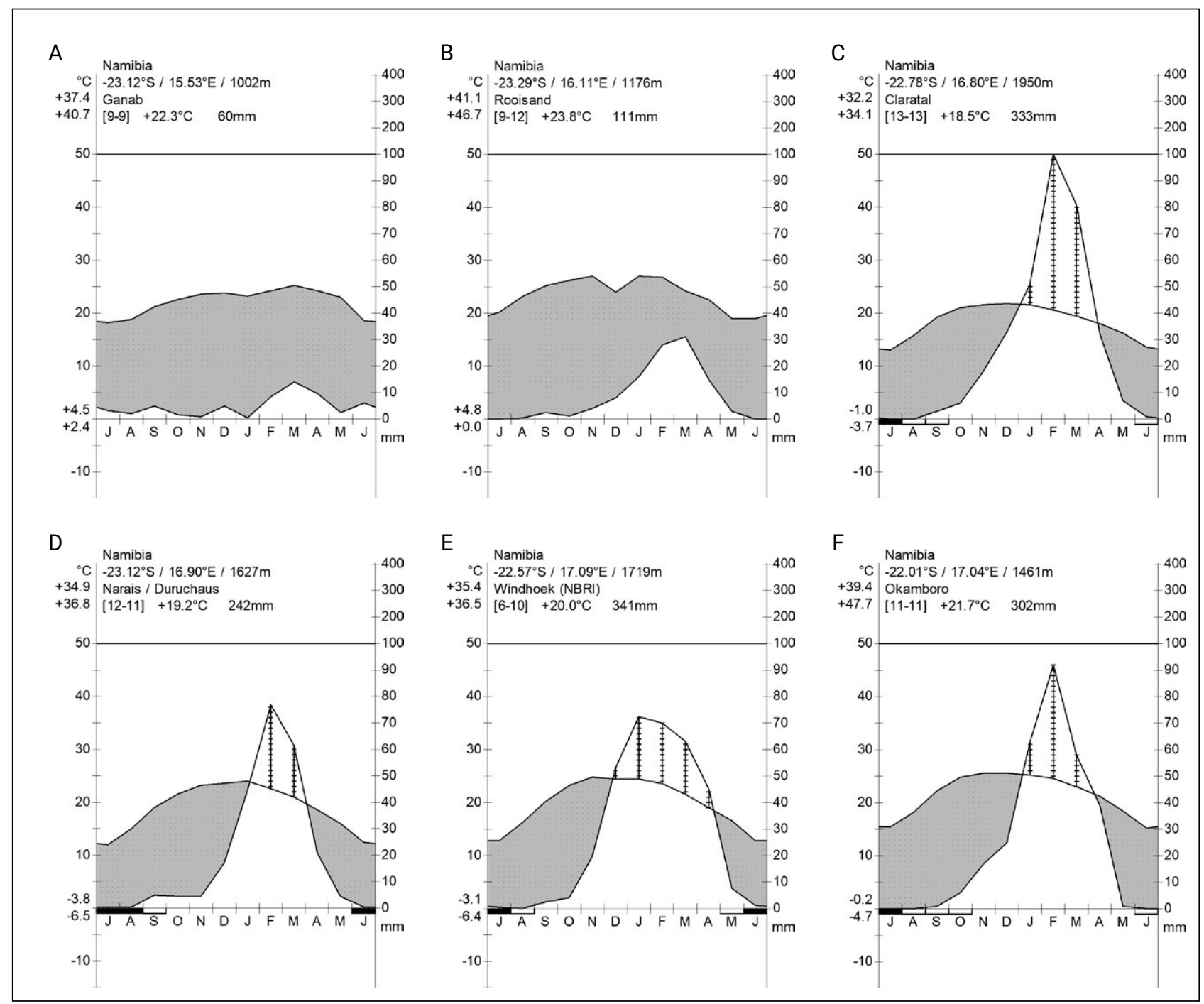

Figure 3. Climate diagrams after Walter et al. (1975) of available automatic weather stations within the study area: Ganab, Rooisand, Claratal, Narais, Windhoek (NBRI) and Okamboro. Data sources: SASSCAL (2020) and BIOTA AFRICA (2009).

of MAP is as high as $90 \%$, in the east around Windhoek the CV of MAP is about 40\% (Mendelsohn et al. 2002). The orographic effect of the escarpment and high mountains in the study area are not known. The desert margins below the escarpment become relatively hot, with maximum temperatures measured well over $40^{\circ} \mathrm{C}$. Frost is also rare or absent here. In contrast, the central highlands are cooler, with maximum temperatures around $36^{\circ} \mathrm{C}$. Frost regularly occurs in the highlands in the winter months between May and August, at places as late as October (Figure 3).

\section{Data sources}

A data set of 1151 relevés with 914 species was selected from the phytosociological database of Namibia (GVID ID AF-NA-001) (Strohbach \& Kangombe 2012). Details of the selected data subsets are listed in Table 1.

The quality of the rainy season, which has an influence on the growth of the vegetation, was derived according to the criteria of Botha (1998). Normal years had an annual precipitation of between the 40th and 70th percentile of long-term precipitation records, whilst extreme years had below the 10th (extreme dry) or above the 90th percentile (extreme wet) annual precipitation.

Data collected by Kellner (1986) was captured from tables in his thesis as the original relevé data (field sheets) were no longer available. These relevés were also collected from $25 \times 25 \mathrm{~m}$ (i.e. $625 \mathrm{~m}^{2}$ ) plots. No accurate position data, nor habitat data, are available for these relevés. Data collected by Burke, Wittneben and Mannheimer (Auas Mountains and Windhoek Townlands) were in the form of species lists on specific sites rather than regular survey plots. Position data are available in most cases, but the habitat data are incomplete. These data were however included, as the sites were limited to specific habitats and limited in sizes (no longer than $100 \mathrm{~m}$, no wider than $10 \mathrm{~m}$ ), i.e. comparable to regular survey sites used for the Vegetation Survey of Namibia project. Especially the data by Burke and Wittneben 
Table 1. Overview of data used for this study. All data form part of GVID ID AF-NA-001 (Strohbach \& Kangombe 2012)

\begin{tabular}{|c|c|c|c|c|c|c|c|}
\hline Relevés & Dataset name & Number & Year & $\begin{array}{l}\text { Season } \\
\text { quality }\end{array}$ & Surveyor & Area of interest & $\begin{array}{l}\text { Reference } \\
\text { (if any) }\end{array}$ \\
\hline 937-1165 & BS_Auas-Oanob & 229 & $\begin{array}{l}2000 \\
\& \\
2002\end{array}$ & $\begin{array}{l}\text { Extreme } \\
\text { wet } \\
\text { Normal }\end{array}$ & B. Strohbach & $\begin{array}{l}\text { Auas-Oanob } \\
\text { Conservancy }\end{array}$ & $\begin{array}{l}\text { (Strohbach } \\
\text { 2017) }\end{array}$ \\
\hline 1833-2180 & Khomas_2004 & 204 & 2004 & Normal & B. Strohbach & $\begin{array}{l}\text { Khomas Hochland } \\
\text { (Kuiseb valley) }\end{array}$ & \\
\hline 2212-2258 & Khomas_2005 & 124 & 2005 & Dry & B. Strohbach & $\begin{array}{l}\text { Khomas Hochland } \\
\text { (Kuiseb valley) }\end{array}$ & \\
\hline 2797-2977 & Kellner_1985 & 181 & 1985 & Normal & K. Kellner & $\begin{array}{l}\text { Daan Viljoen, } \\
\text { Claratal, Bergvlug }\end{array}$ & (Kellner 1986) \\
\hline $\begin{array}{l}5798-5854 \\
\text { and 5900- } \\
5914 \text { and } \\
5980-5987\end{array}$ & Zuna_2005 & 80 of 204 & 2005 & Dry & Z. September & $\begin{array}{l}\text { Biota transect Aris } \\
\text { to Witvlei (limited to } \\
17^{\circ} 30^{\prime} \text { East) }\end{array}$ & \\
\hline 7114-7140 & $\begin{array}{l}\text { BS-SK_- } \\
\text { Khomas_2007 }\end{array}$ & 27 & 2007 & Normal & $\begin{array}{l}\text { B. Strohbach } \\
\& \text { S. Kruger }\end{array}$ & Windhoek area & \\
\hline 9438-9564 & $\begin{array}{l}\text { BS_- } \\
\text { Khomas_2009 }\end{array}$ & 127 & 2009 & Wet & B. Strohbach & $\begin{array}{l}\text { Northern and } \\
\text { western Khomas }\end{array}$ & \\
\hline 9565-9598 & $\begin{array}{l}\text { Auas_- } \\
W+\bar{B} \_2004\end{array}$ & 34 & 2004 & Normal & $\begin{array}{l}\text { A. Burke \& } \\
\text { M. Wittneben }\end{array}$ & $\begin{array}{l}\text { Auas Mountain } \\
\text { Range }\end{array}$ & $\begin{array}{l}\text { (Burke \& } \\
\text { Wittneben } \\
2007 ; \\
\text { Strohbach } \\
2017 \text { ) }\end{array}$ \\
\hline $\begin{array}{l}10192- \\
10221\end{array}$ & $\begin{array}{l}\text { CM_Windhoek- } \\
\text { townlands }\end{array}$ & 30 & 2009 & Wet & $\begin{array}{l}\text { C. } \\
\text { Mannheimer }\end{array}$ & $\begin{array}{l}\text { Windhoek } \\
\text { Townlands }\end{array}$ & \\
\hline $\begin{array}{l}10612- \\
10632\end{array}$ & BS_Narais_2011 & 21 & 2011 & Wet & B. Strohbach & Narais observatory & $\begin{array}{l}\text { BIOTA } \\
\text { observatory } \\
\text { (Jürgens et al. } \\
\text { 2010) }\end{array}$ \\
\hline $\begin{array}{l}11475- \\
11540\end{array}$ & $\begin{array}{l}\text { BS } \\
\text { Midgard-2014 }\end{array}$ & 66 & 2014 & $\begin{array}{l}\text { Extreme } \\
\text { wet }\end{array}$ & B. Strohbach & $\begin{array}{l}\text { Midgard Country } \\
\text { Estate (south) }\end{array}$ & \\
\hline $\begin{array}{l}70001- \\
70028\end{array}$ & Ovitoto_2001 & 28 & 2001 & Normal & T. Sheuyange & Ovitoto Observatory & $\begin{array}{l}\text { BIOTA } \\
\text { observatory } \\
\text { (Jürgens et al. } \\
\text { 2010) }\end{array}$ \\
\hline
\end{tabular}

(2007) covered extreme, inaccessible habitats, making the data invaluable for the completeness of this study.

All other surveys followed the guidelines of the Vegetation Survey of Namibia project, i.e. were surveyed on a $20 \times 50 \mathrm{~m}\left(1000 \mathrm{~m}^{2}\right)$ plot, whilst plot layout was restricted to a specific habitat. In cases where the nature of the habitat did not allow a $20 \mathrm{~m} \times 50 \mathrm{~m}$ sized plot (e.g. riverine habitats, rock outcrops), the plot shape was adapted to fit the habitat, without reducing the size, nor moving into a different habitat. The size of $20 \times 50 \mathrm{~m}$ was chosen as suitable for an arid savanna and conforms to size criteria proposed by Brown et al. (2013). For these relevés, the position as determined by GPS, as well as habitat descriptors related to landscape, topography, lithology and stone cover have been noted.
Unknown species were collected for identification in the National Herbarium of Namibia (WIND). Species' nomenclature follows Klaassen and Kwembeya (2013), with the exception of the genus Acacia s.I., for which Kyalangalilwa et al. (2013) was followed.

\section{Classification procedures}

An initial classification was done using modified TWINSPAN (Roleček et al. 2009), with average Sørensen as distance measure, and utilising pseudospecies cut levels at 0 and $5 \%$ cover to differentiate between low-cover desert margin vegetation and inland vegetation at higher cover values. This classification was based on synusial data (i.e. trees, shrubs, dwarf shrubs and grasses 
only) (Gillet \& Julve 2018), and resulted in three clusters. These clusters were interpreted as representing the Pre-Namib and Escarpment zone, the central Khomas Hochland as well as a third group comprising riverine habitats and lowlands surrounding the Khomas Hochland. This classification result was used to split the data set into three subsets for further analysis.

The three clusters were further classified using the modified TWINSPAN classification algorithm, always using average Sørensen as distance measure, and utilising pseudospecies. For the Pre-Namib/Escarpment zone cluster, these were kept at 0 and 5\%; for the other clusters cut levels were set at 0 and $10 \%$. This difference in pseudospecies cut levels was necessary because the Pre-Namib has an inherent lower vegetation cover than the inland vegetation. In the case of Cluster 3 (riverine and lowland habitats), the data set was again split into two subsets after an initial classification using synusial data. The level of splitting was determined using peaks in crispness values (Botta-Dukát et al. 2005).

The classification of the clusters using synusial data was transferred to the full data set. Analysis of the resulting clusters revealed partial mixing of relevés between associations, or in several cases, known units to be included in other associations. This prompted a refinement of the classification results using Cocktail procedures (Bruelheide \& Flintrop 1994; Bruelheide 1997), based on existing descriptions (e.g. Kellner 1986; Strohbach 2017), or on field observations. A detailed account of these Cocktail refinements is presented in the Results section of this paper.

Once an ecologically interpretable result was achieved, phytosociological tables were compiled and the synopsis for various associations extracted. Diagnostic species were determined using the phi coefficient of association (Chytrý et al. 2002). For this calculation the numbers of relevés were standardised following Tichý and Chytrý (2006). Species with phi $\geq 40$ were considered as diagnostic and with phi $\geq 60$ as highly diagnostic; however, species with a non-significant fidelity at $\alpha=0.05$ using Fisher's exact test were omitted. Species occurring with at least a $60 \%$ frequency were regarded as constant and with at least an $80 \%$ frequency as highly constant.

\section{Further descriptors of the associations}

The average structure for each grouping (i.e. average tree, shrub, dwarf shrub, perennial grass, annual grass and herb cover) was calculated using the available growth form data. Descriptions follow Edwards (1983). For the species density (number of species per $1000 \mathrm{~m}^{2}$ ), the relevé data from Kellner (1986) were excluded, as these were sampled on $625 \mathrm{~m}^{2}$ plots (25 $\times 25 \mathrm{~m}$ ), not $1000 \mathrm{~m}^{2}$ plots as for all other relevés. In addition, an estimate of potential species richness for the association has been calculated with a first order Jackknife as proposed by Heltshe and Forrester (1983) as well as Palmer (1990).

\section{Higher syntaxonomy}

Due to the extensive refining of clusters with Cocktail, partially resulting in splitting of clusters or the definition of new clusters, the initial classification dendrograms could not be used as an indication of higher-order syntaxonomy as is customary (e.g. Luther-Mosebach et al. 2012). Instead, synoptic tables of the associations were prepared using percentage frequency for all four classifications. The synopsis of each association was taken as a pseudo-relevé, and these were combined into a single data set for classification with modified TWINSPAN (Roleček et al. 2009). No pseudospecies were used for this classification. This approach follows broadly the approached used by Winterbach et al. (2000).

\section{Results}

\section{First classification results and Cocktail refinements}

The first classification resulted in three major vegetation zones, namely the Pre-Namib and Escarpment zone, the Khomas Hochland proper and the riverine habitats and lowlands vegetation surrounding the Khomas Hochland. The latter was further subdivided into two subsets for further classification. Cocktail refinements were necessary on all four clusters. Details of these refinements are provided in Table 2.

\section{Pre-Namib and Escarpment zone}

The vegetation of the Pre-Namib (Vornamib sensu Giess (1962, 1998) and Escarpment zone is dominated by the plant families Poaceae, Fabaceae, Bignoniaceae and Burseraceae, in descending order of importance. The classification resulted in seven associations, which are formally described according to the International Code of Phytosociological Nomenclature (Weber et al. 2000). The synoptic table for these is presented in Appendix 1, and the phytosociological table in Appendix 2, available online only (DOI: http://dx.doi.org/ 10.38201/btha.abc.v51.i2.s4a, DOI: http://dx.doi.org/ 10.38201/btha.abc.v51.i2.s4b).

Within the synopsis, basic statistics on the association (or other syntaxa) are given, as derived from the analysis of clusters in Juice. Highly diagnostic species (with phi coefficient $>60$ ) and highly constant species (occurring in more than $80 \%$ of relevés) are indicated in bold. All structural descriptions follow Edwards (1983). Landscape descriptors follow conventions of the Digital 
Table 2. Refinements necessary to the classification results for improved ecological interpretability

\begin{tabular}{|c|c|c|c|}
\hline Unit changed & Selection based on following criteria & Relevés involved & Based on \\
\hline \multicolumn{4}{|c|}{$\begin{array}{l}\text { Cluster 1: Pre-Namib and Escarpment zone: } \\
\text { This data cluster consisted of } 279 \text { relevés and } 329 \text { species. The synusial data had only } 121 \text { species. Classification of this } \\
\text { subset resulted in five clusters, which were refined as follows: }\end{array}$} \\
\hline $\begin{array}{l}\text { Karpfenkliffs (Association } \\
1.1 \text { ) }\end{array}$ & $\begin{array}{l}\text { Adenolobus pechuelii, Enneapogon } \\
\text { desvauxii, Fagonia isotricha }\end{array}$ & 8 relevés from Cluster 1 & Field observations \\
\hline $\begin{array}{l}\text { Rostock sand drift plains } \\
\text { (Association 1.3) }\end{array}$ & $\begin{array}{l}\text { Crotalaria podocarpa, Sesuvium } \\
\text { sesuvioides, Crinum macowani, } \\
\text { Kohautia caespitosa, Stipagrostis } \\
\text { obtusa, Grielum sinuatum }\end{array}$ & 7 relevés from Cluster 1 & Field observations \\
\hline
\end{tabular}

Gravel plains of Pre-

Namib (Association 1.2)

Remainder of Cluster 1

\title{
Cluster 2: Khomas Hochland proper:
}

This data cluster consisted of 350 relevés with 588 species. The synusial data set had only 198 species. Classification of this subset resulted in five clusters. Refinements were done as follows:

\begin{tabular}{|c|c|c|c|}
\hline $\begin{array}{l}\text { Steep cliff faces } \\
\text { (Association 2.2) }\end{array}$ & $\begin{array}{l}\text { Ficus ilicina, Pennisetum foermeranum, } \\
\text { Steganotaenia araliacea. A minimum of } \\
\text { two of these species had to be present }\end{array}$ & $\begin{array}{l}5 \text { relevés from Cluster } 4 \text { (rock } \\
\text { outcrops) }\end{array}$ & Kellner 1986 \\
\hline Cluster 3 senso lato & $\begin{array}{l}\text { Osyris lanceolata, Hypoestes forskaolii, } \\
\text { Danthoniopsis ramosa }\end{array}$ & 13 relevés from Cluster 5 & Strohbach 2017 \\
\hline $\begin{array}{l}\text { High altitude mountain } \\
\text { veld of the south-facing } \\
\text { slopes (Association 2.3) }\end{array}$ & $\begin{array}{l}\text { Jamesbrittenia pallida, Selago } \\
\text { alopecuroides, Frankenia pomonensis, } \\
\text { Eriocephalus dinteri }\end{array}$ & Split from Cluster 3 (8 relevés) & Strohbach 2017 \\
\hline $\begin{array}{l}\text { High altitude mountain } \\
\text { veld of the north-facing } \\
\text { slopes (Association 2.4) }\end{array}$ & $\begin{array}{l}\text { Selago angustibractea, Lopholaena } \\
\text { cneorifolia, Cheilanthes multifida, } \\
\text { Babiana hypogea, Eriocephalus } \\
\text { scariosus and Adromischus species }\end{array}$ & Split from Cluster 3 (8 relevés) & Strohbach 2017 \\
\hline $\begin{array}{l}\text { Mid-altitude mountain } \\
\text { veld (Association 2.5) }\end{array}$ & & Remainder of Cluster 3 & \\
\hline $\begin{array}{l}\text { Oamites mountain veld } \\
\text { (Association } 2.7 \text { ) }\end{array}$ & $\begin{array}{l}\text { Ornithoglossum calcicola and } \\
\text { Melhania damarana }\end{array}$ & Split from Cluster 5 (9 relevés) & Strohbach 2017 \\
\hline $\begin{array}{l}\text { Khomas Hochland } \\
\text { mountain veld } \\
\text { (Association 2.8) }\end{array}$ & & Remainder of Cluster 5 & \\
\hline
\end{tabular}

\begin{abstract}
Cluster 3: Riverine habitats:
This data cluster consisted of 59 relevés and 304 species. The synusial data contained only 114 species. Classification of this subset resulted in eight clusters. Due to high intrinsic variation however, not all associations were ecological interpretable, and extensive refinement, including partial recombination of relevés into associations was necessary.
\end{abstract}

Dry riverbeds (Association

3.2)

Cluster 5 senso lato

Riverine sand banks (Association 3.3)

Inland riparian woodlands (Association 3.5)

Recombined clusters 2, 3 and 4 as one

Split into two namaquensis

High abundance of Stipagrostis namaquensis
Cluster 5A (3 relevés), as well as 1 relevé from Cluster 7 and 1 relevé from Cluster 8

Clusters 5B and 6, as well as several relevés from the surrounding lowlands (Cluster 4 , mostly relevés sampled by Kellner (1986)) found to fit into this group. These were manually moved here.
Strohbach 2017

Strohbach 2017; Kellner 1986 
Table 2. Refinements necessary to the classification results for improved ecological interpretability (continued)

\begin{tabular}{|c|c|c|c|}
\hline Unit changed & Selection based on following criteria & Relevés involved & Based on \\
\hline \multicolumn{4}{|c|}{ Cluster 3: Riverine habitats (continued) } \\
\hline $\begin{array}{l}\text { Omirimbi vegetation } \\
\text { (Association } 3.4 \text { ) }\end{array}$ & $\begin{array}{l}\text { Manual selection according to habitat } \\
\text { description, verified with Cocktail } \\
\text { based on Tragus berteronianus, } \\
\text { Schmidtia pappophoroides, } \\
\text { Themeda triandra, Talinum caffrum, } \\
\text { Platycarphella carlinoides, Monsonia } \\
\text { angustifolia, Microchloa caffra, Chloris } \\
\text { virgata }\end{array}$ & $\begin{array}{l}\text { Remainder of clusters } 5 \text { and } 6 \text {, } \\
\text { but weakly defined }\end{array}$ & $\begin{array}{l}\text { Volk \& Leippert } \\
1971 ; \text { Strohbach } \\
2017\end{array}$ \\
\hline $\begin{array}{l}\text { Riparian woodlands } \\
\text { of the westerly rivers } \\
\text { (Association 3.6) }\end{array}$ & $\begin{array}{l}\text { Tamarix usneoides, Salvadora persica, } \\
\text { Euclea pseudebenus, Stipagrostis } \\
\text { hochstetteriana and Faidherbia albida }\end{array}$ & $\begin{array}{l}\text { Cluster } 7 \text { (remainder) and } 1 \\
\text { relevé from Cluster } 6\end{array}$ & Field observations \\
\hline $\begin{array}{l}\text { Big inland rivers } \\
\text { (Association 3.8) and } \\
\text { Omeya plains vegetation } \\
\text { (Association } 4.7 \text { ) }\end{array}$ & Geographical location and habitat & $\begin{array}{l}\text { Several relevés grouped into } \\
\text { Cluster } 8 \text { (big inland rivers) } \\
\text { were found to belong to the } \\
\text { Omeya plains according to their } \\
\text { location. These were manually } \\
\text { moved to the data subset of } \\
\text { Cluster } 4 \text {, Association } 4.7\end{array}$ & \\
\hline
\end{tabular}

Cluster 4: Lowlands surrounding the Khomas Hochland:

This data cluster consisted of 462 relevés and 688 species. The synusial data set contained only 227 species. Classification of this data set resulted in ten clusters. On closer inspection, these were found to be fairly mixed due to the synusial data reduction, requiring extensive refinement through Cocktail procedures as follows:

$\begin{array}{llll}\text { Oanob Plateau } & \text { Panicum lanipes, Plinthus sericeus, } & \text { Clusters } 2 \text { and } 3 & \text { Strohbach } 2017 \\ \text { (Association 4.2) } & \text { Pteronia eenii, Pentzia incana and } & & \end{array}$
Blepharis integrifolia

Cluster 3 senso lato

Remainder of clusters 2 and 3

(weakly defined)

$\begin{array}{llll}\text { Gölschau plains } & \text { Aptosimum spinescens, Eriocephalus } & \text { From Cluster } 3 \text { senso lato } & \text { Field observations } \\ \text { (Association 4.3) } & \text { ericoides, Geigeria pectidea and } & \\ & \text { Galenia africana }\end{array}$

$\begin{array}{ll}\text { Southern Khomas } & \text { Aizoon schellenbergii, Panicum } \\ \text { (Association 4.4) } & \text { arbusculum, Hibiscus discophorus, } \\ & \text { Kohautia cynanchica and Aptosimum } \\ \text { albomarginatum }\end{array}$

Degraded/bush encroached vegetation of the Khomas Hochland

From Cluster 3 senso lato

Strohbach 2017

(Sub-association 4.8.1)

\begin{tabular}{llll}
$\begin{array}{l}\text { Khomas Hochland } \\
\text { lowlands (Association 4.6) }\end{array}$ & $\begin{array}{l}\text { Senegalia erubescens, Combretum } \\
\text { apiculatum, Grewia flavescens and } \\
\text { Dichrostachys cinerea (minimum of } \\
\text { two species, with high abundance of } \\
\text { Senegalia erubescens) }\end{array}$ & $\begin{array}{l}\text { Cluster 5, with extra relevés } \\
\text { from Cluster 10 }\end{array}$ & Field observations \\
$\begin{array}{ll}\text { Khomas Hochland } \\
\text { lowlands (Sub-association }\end{array}$ & Vachellia reficiens at high abundance & $\begin{array}{l}\text { Remainder of Cluster 10, } \\
\text { excluding clusters } 8 \text { and } 9\end{array}$ & Field observations \\
$\begin{array}{ll}\text { K.8.1) } \\
\text { Khomas Hochland } \\
\text { lowlands (Association 4.8) }\end{array}$ & $\begin{array}{l}\text { The recombined Clusters } \\
7 \text { and 10, as well as the } \\
\text { original Clusters } 8 \text { and } 9 \text { were } \\
\text { recognised as sub-associations } \\
\text { of association } 4.8 .\end{array}$ \\
\hline
\end{tabular}

Remainder of Cluster 3 senso Strohbach 2017 lato, combined with Cluster 9 
Soil and Terrain Database (SOTER) of FAO (FAO 1993). Specifically, the following slope classes apply:

- Flat: $\quad 0-1 \% / 0-2 \%$

- Gently undulating: $1-3^{\circ} / 2-5 \%$

- Undulating: $\quad 3-6^{\circ} / 5-10 \%$

- Rolling: $\quad 6-9^{\circ} / 10-15 \%$

- Moderately steep: $9-17^{\circ} / 15-30 \%$

- Steep: $\quad 17-30^{\circ} / 30-60 \%$

- Very steep: $\quad>30^{\circ} />60 \%$

This format is also followed for all further descriptions in this paper.

\subsection{Enneapogono desvauxii- Adenoloboetum pechuelii ass. nov.}

\section{Synopsis:}

Number of relevés: 8

Type relevé: 2065 (holotype), sampled on 15 March 2005 at $23^{\circ} 28^{\prime} 01^{\prime \prime} \mathrm{S}, 16^{\circ} 05^{\prime} 22^{\prime \prime} \mathrm{E}$

Number of species observed: 27

Estimated number of species: 46

Average species density per $1000 \mathrm{~m}^{2}: 14$

Diagnostic species: Adenolobus pechuelii, Fagonia isotricha var. isotricha, Enneapogon desvauxii, Indigofera auricoma

Constant species: Euphorbia glanduligera, Eragrostis nindensis, Stipagrostis hirtigluma, Tribulus zeyheri

These low desert herblands (Figures $4 \mathrm{~A}$ and $5 \mathrm{~B}$ ) are dominated by Eragrostis nindensis and Enneapogon desvauxii. This association occurs on old eroded fluvial deposits commonly referred to as 'Karpfenkliff Conglomerate' (Ward 1987) along the upper reaches of the Kuiseb and Gaub canyons, with altitudinal ranges between 800 and $1100 \mathrm{~m}$ asl. The substrate consists of carbonate-cemented conglomerates, which are between 40 and $60 \mathrm{~m}$ deep. The erosion of these conglomerates results in a steeply dissected hill landscape. Low rainfall (between 100 and $150 \mathrm{~mm}$ Mean Annual Precipitation - MAP), high runoff and a compact substrate allowing little infiltration result in this depauperated form (diversity- and cover-wise) of the Enneapogono desvauxii-Eragrostietum nindensis. Because of its unique habitat, it is recognised as an association.

\subsection{Enneapogono desvauxii- Eragrostietum nindensis ass. nov.}

\section{Synopsis:}

Number of relevés: 82

Type relevé: 9439 (holotype), sampled on 10 March 2009 at $22^{\circ} 54^{\prime} 06^{\prime \prime} \mathrm{S}, 16^{\circ} 37^{\prime} 36^{\prime \prime} \mathrm{E}$

Number of species observed: 64

Estimated number of species: 111

Average species density per $1000 \mathrm{~m}^{2}: 16$
Diagnostic species: Enneapogon desvauxii

Constant species: Eragrostis nindensis, Tribulus zeyheri, Euphorbia glanduligera, Stipagrostis ciliata, Stipagrostis hirtigluma

These low desert grasslands (sometimes rather desert shrublands) are dominated by Eragrostis nindensis and various other grass, herb and dwarfshrub species (Figures 4B and 5B). This association occurs on the expansive calcrete gravel plains of the Pre-Namib and has been described by Jürgens et al. (2013) as 'eastern calcrete plains grasslands'. The altitude ranges between 780 and $1300 \mathrm{~m}$ asl, and the landscape is generally flat. MAP ranges between 50 and $150 \mathrm{~mm}$, but because of the reduced run-off and looser substrate, this association is far more species rich compared to the Enneapogono desvauxii-Adenoloboetum pechuelii (depending on the quality of the rainfall season).

\subsection{Crotalario podocarpae- Stipagrostioetum obtusae ass. nov.}

\section{Synopsis:}

Number of relevés: 7

Type relevé: 1997 (holotype), sampled on 19 February 2004 at $23^{\circ} 20^{\prime} 49^{\prime \prime} \mathrm{S}, 15^{\circ} 56^{\prime} 58^{\prime \prime} \mathrm{E}$

Number of species observed: 23

Estimated number of species: 34

Average species density per $1000 \mathrm{~m}^{2}: 11$

Diagnostic species: Crotalaria podocarpa, Stipagrostis obtusa, Sesuvium sesuvioides, Grielum sinuatum, Crinum macowanii, Kohautia caespitosa subsp. brachyloba, Limeum myosotis, Stipagrostis ciliata

These short open grasslands are dominated by Stipagrostis ciliata and Stipagrostis obtusa (Figures 4C and 5C), occurring on sand drift plains in the Pre-Namib. Striking examples are found along the western end of the C26 main road before joining the C14. The topography is an undulating sand drift plain, ranging between 1050 and $1100 \mathrm{~m}$ asl. This area receives between 50 and $100 \mathrm{~mm}$ MAP.

\subsection{Tribulocarpo dimorphantho- vachellietum eriolobae ass. nov.}

\section{Synopsis:}

Number of relevés: 4

Type relevé: 2013 (holotype), sampled on 20 February 2004 at $23^{\circ} 15^{\prime} 57^{\prime \prime} \mathrm{S}, 16^{\circ} 07^{\prime} 28^{\prime \prime} \mathrm{E}$

Number of species observed: 22

Estimated number of species: 26

Average species density per $1000 \mathrm{~m}^{2}: 15$

Diagnostic species: Xenostegia tridentata subsp. angustifolia, Requienia sphaerosperma, Harpagophytum 

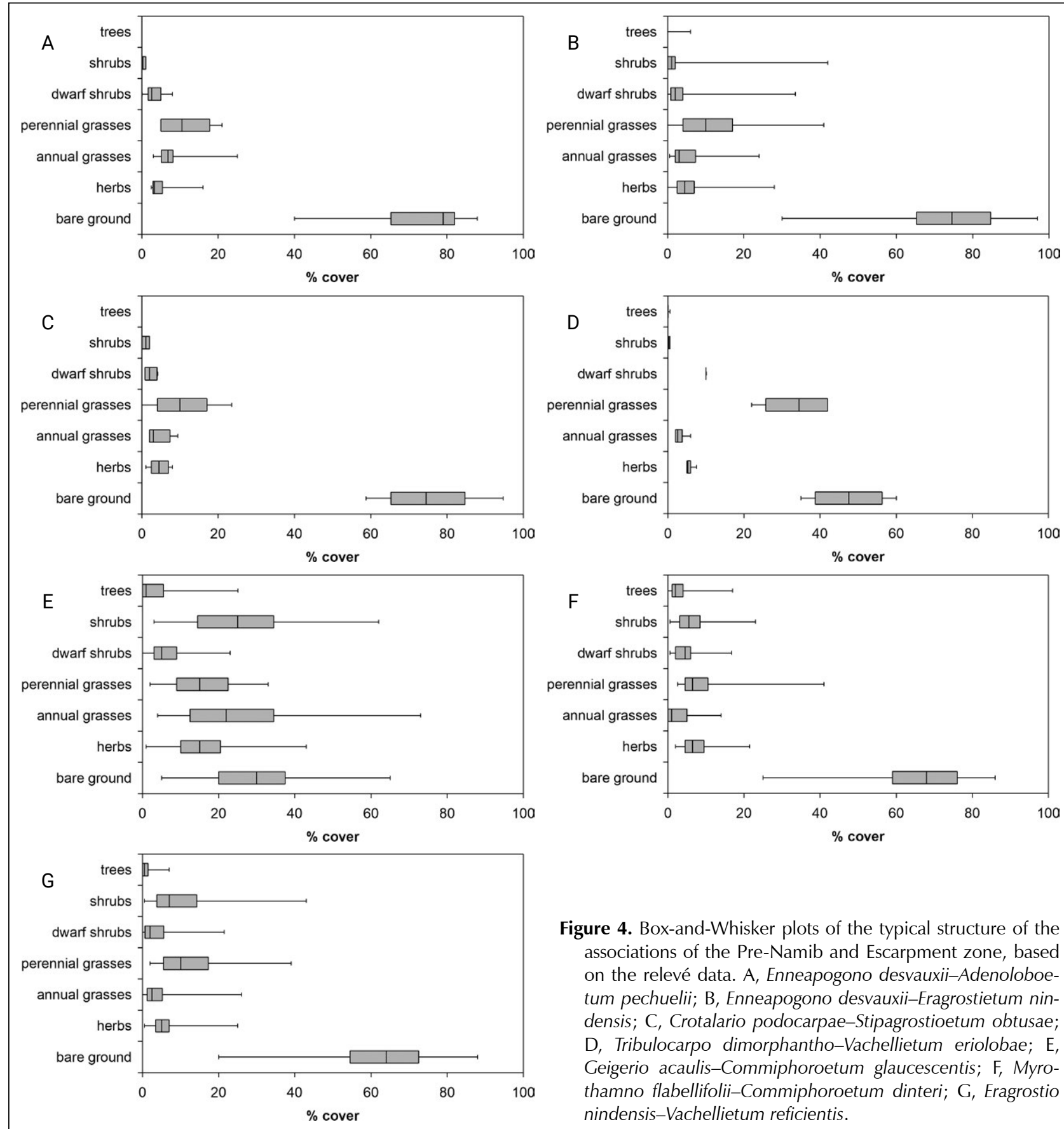

Figure 4. Box-and-Whisker plots of the typical structure of the associations of the Pre-Namib and Escarpment zone, based on the relevé data. A, Enneapogono desvauxii-Adenoloboetum pechuelii; B, Enneapogono desvauxii-Eragrostietum nindensis; C, Crotalario podocarpae-Stipagrostioetum obtusae; D, Tribulocarpo dimorphantho-Vachellietum eriolobae; E, Geigerio acaulis-Commiphoroetum glaucescentis; F, Myrothamno flabellifolii-Commiphoroetum dinteri; G, Eragrostio nindensis-Vachellietum reficientis.

procumbens, Hermannia guerkeana, Oxygonum alatum, Tribulocarpus dimorphanthus, Brachiaria glomerata, Ipomoea magnusiana, Vachellia erioloba, Gisekia africana, Centropodia glauca, Stipagrostis hochstetteriana, Dicoma capensis, Stipagrostis ciliata, Heliotropium nelsonii

Constant species: Stipagrostis uniplumis var. uniplumis

This short desert woodland is dominated by Stipagrostis uniplumis var. uniplumis and Stipagrostis ciliata with a scattered cover of Vachellia erioloba trees (Figures 4D and 5D). It is situated further inland from the Crotalario podocarpae-Stipagrostioetum obtusae in the valleys below the escarpment at an altitudinal range of between 1200 and $1250 \mathrm{~m}$. The substrate is aeolian Kalahari sands, thus supporting typical Kalahari elements like Vachellia erioloba, Brachiaria glomerata, Requienia sphaerosperma and Harpagophytum procumbens. MAP ranges between 100 and $150 \mathrm{~mm}$.

\subsection{Geigerio acaulis-Commiphoroetum glaucescentis ass. nov.}

\section{Synopsis:}

Number of relevés: 59

Type relevé: 9467 (holotype), sampled on 12 March 2009 at $22^{\circ} 21^{\prime} 16^{\prime \prime} \mathrm{S}, 15^{\circ} 49^{\prime} 55^{\prime \prime} \mathrm{E}$

Number of species observed: 165 

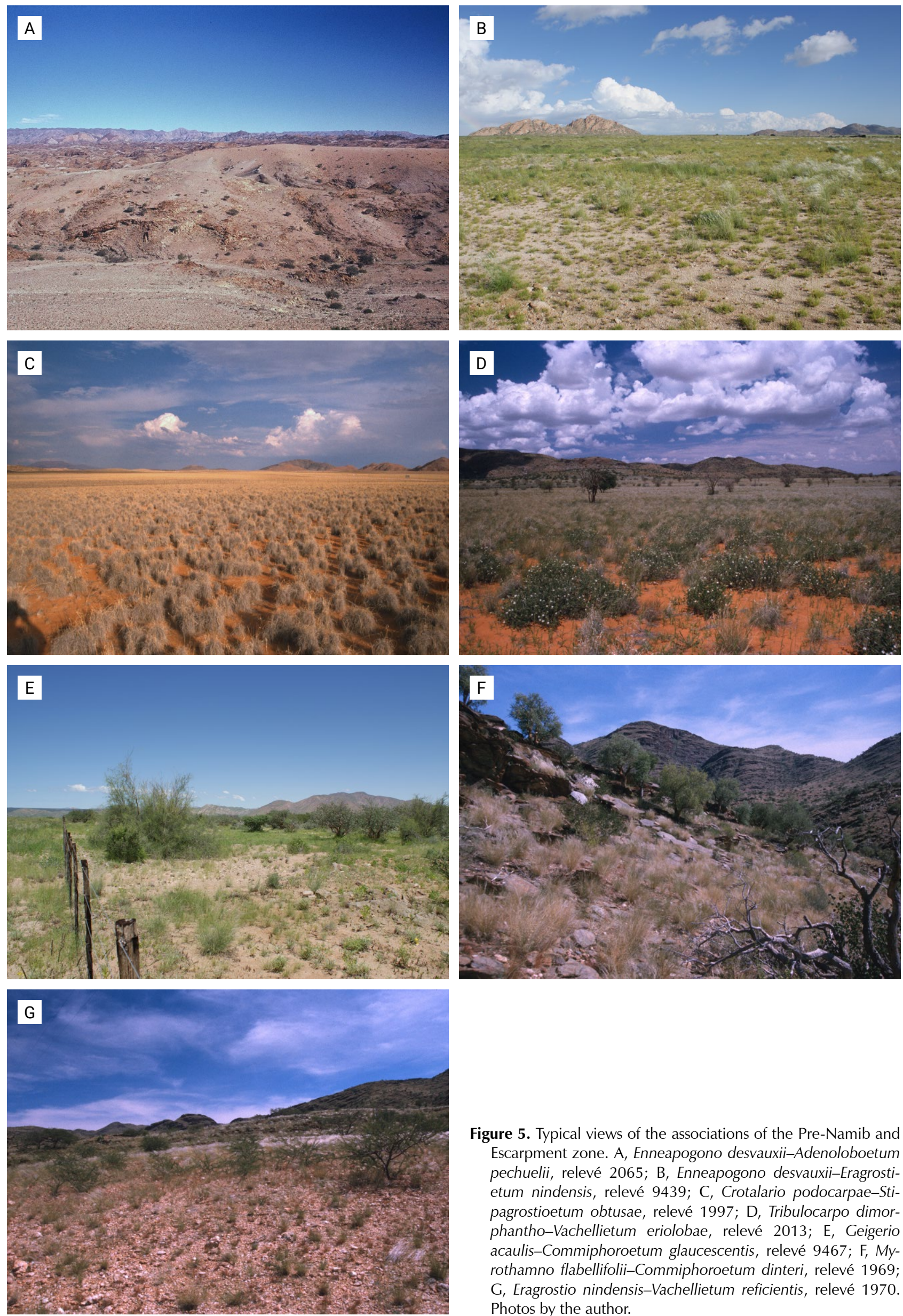

Figure 5. Typical views of the associations of the Pre-Namib and Escarpment zone. A, Enneapogono desvauxii-Adenoloboetum pechuelii, relevé 2065; B, Enneapogono desvauxii-Eragrostietum nindensis, relevé 9439; C, Crotalario podocarpae-Stipagrostioetum obtusae, relevé 1997; D, Tribulocarpo dimorphantho-Vachellietum eriolobae, relevé 2013; E, Geigerio acaulis-Commiphoroetum glaucescentis, relevé 9467; F, Myrothamno flabellifolii-Commiphoroetum dinteri, relevé 1969; G, Eragrostio nindensis-Vachellietum reficientis, relevé 1970. Photos by the author. 
Estimated number of species: 214

Average species density per $1000 \mathrm{~m}^{2}: 33$

Diagnostic species: Schmidtia kalahariensis, Aristida adscensionis, Melinis repens subsp. grandiflora, Lycium bosciifolium, Aristida effusa, Eragrostis porosa, Enneapogon cenchroides, Geigeria acaulis, Albizia anthelmintica, Aptosimum arenarium, Merremia bipinnatipartita, Senegalia erubescens, Grewia tenax, Kyphocarpa angustifolia

Constant species: Stipagrostis uniplumis var. uniplumis, Eragrostis nindensis, Stipagrostis hochstetteriana, Boscia foetida, Vachellia reficiens

These semi-open high shrublands are strikingly characterised by scattered trees of Commiphora glaucescens (Figures $4 \mathrm{E}$ and $5 \mathrm{E}$ ). They occur on the slightly undulating plains surrounding Otjimbingwe, on Donkerhuk granites, north of the central Khomas Hochland complex. Typical for these granite-derived soils in arid environments is a very high ( $80 \%$ or more) cover by granitic gravel. The altitude ranges between 900 and $1300 \mathrm{~m}$ asl, whilst MAP ranges between 150 and $250 \mathrm{~mm}$.

\subsection{Myrothamno flabellifolii- Commiphoroetum dinteri ass.nov.}

\section{Synopsis:}

Number of relevés: 42

Type relevé: 1968 (holotype), sampled on 18 February 2004 at $23^{\circ} 01^{\prime} 49^{\prime \prime}$ S, $16^{\circ} 07^{\prime} 24^{\prime \prime} \mathrm{E}$

Number of species observed: 123

Estimated number of species: 173

Average species density per $1000 \mathrm{~m}^{2}: 29$

Diagnostic species: Commiphora dinteri, Forsskaolea viridis, Sterculia africana, Myrothamnus flabellifolius, Cheilanthes hirta, Talinum caffrum, Commiphora glaucescens, Elephantorrhiza suffruticosa, Calostephane marlothiana, Monechma spartioides, Blepharis obmitrata, Setaria appendiculata, Amphiasma divaricatum, Triraphis ramosissima, Dyerophytum africanum, Barleria lancifolia

Constant species: Stipagrostis uniplumis var. uniplumis, Eragrostis nindensis, Tribulus zeyheri, Tephrosia dregeana var. dregeana

These low open bushlands are characterised by a variety of stem succulents typical of the escarpment zone (Figures $4 \mathrm{~F}$ and $5 \mathrm{~F}$ ). They occur on the inselberg ranges along the Pre-Namib fringes as well as the lower escarpment zone, at an altitudinal range between 1050 and $1500 \mathrm{~m}$ asl. The topography consists of steep mountain slopes generally with a gradient of well above $30 \%$, as well as with considerable stone cover (up to 80\%), mostly small, medium and large stones. MAP ranges between 100 and $200 \mathrm{~mm}$.

\subsection{Eragrostio nindensis-Vachellietum reficientis ass. nov.}

\section{Synopsis:}

Number of relevés: 77

Type relevé: 1970 (holotype), sampled on 18 February 2004 at $23^{\circ} 02^{\prime} 24^{\prime \prime} \mathrm{S}, 16^{\circ} 08^{\prime} 18^{\prime \prime} \mathrm{E}$

Number of species observed: 97

Estimated number of species: 153

Average species density per $1000 \mathrm{~m}^{2}: 23$

Diagnostic species: none

Constant species: Eragrostis nindensis, Stipagrostis uniplumis var. uniplumis, Euphorbia glanduligera, Tribulus zeyheri, Entoplocamia aristulata, Catophractes alexandri, Monsonia senegalensis, Leucosphaera bainesii

These tall open shrublands are dominated by Stipagrostis uniplumis var. uniplumis, Vachellia reficiens, Catophractes alexandri, Eragrostis nindensis, Enneapogon desvauxii, Aristida adscensionis and Senegalia erubescens (Figures $4 \mathrm{G}$ and $5 \mathrm{G}$ ). They occur on rolling to moderately steep (10-30\%) plains and footslopes of the escarpment, often occurring far inland in valleys of the escarpment. Stone cover is not as high, roughly $40 \%$, again mostly small, medium and large stones. The altitude ranges between 950 and $1400 \mathrm{~m}$ asl, whilst MAP ranges between 100 and $250 \mathrm{~mm}$.

\section{Khomas Hochland proper}

The vegetation of the Khomas Hochland is dominated by the plant families Poaceae, Asteraceae, Fabaceae and Scrophulariaceae. The classification resulted in eight associations, which are formally described according to the International Code of Phytosociological Nomenclature (Weber et al. 2000) below (with one exception). The synoptic table for these is presented in online Appendix 1, and the phytosociological table in online Appendix 2.

\subsection{Digitario erianthae-Euryopietum walterorum ass. nov.}

\section{Synopsis:}

Number of relevés: 6

Type relevé: 1838 (holotype), sampled on 9 February 2004 at $23^{\circ} 20^{\prime} 19^{\prime \prime} \mathrm{S}, 16^{\circ} 13^{\prime} 50^{\prime \prime} \mathrm{E}$

Number of species observed: 44

Estimated number of species: 70

Average species density per $1000 \mathrm{~m}^{2}: 15$

Diagnostic species: Panicum lanipes, Euryops walterorum, Eriospermum bakerianum subsp. bakerianum, Hypertelis salsoloides, Boophone disticha 
Constant species: Eragrostis nindensis, Digitaria eriantha

This moderately closed, short shrubland is dominated by the name-giving Euryops walterorum, Eriocephalus dinteri and Digitaria eriantha (Figures 6A and 7A). The occurrence of Euryops walterorum is restricted to the Gamsberg Plateau (i.e. a limited-range endemic) (Nordenstam 1966; Loots 2005), which is 210 ha in size. The plateau consists of a fine-grained quartzite layer $\pm 30 \mathrm{~m}$ thick, at an altitude $2347 \mathrm{~m}$ asl (Wittig 1976; Schalk 1983). The topography is near flat but displays a conspicuous cover by large stones of roughly $40 \%$. The plateau receives an estimated $150 \mathrm{~mm}$ MAP, based on general rainfall maps (Mendelsohn et al. 2002). This, however, does not take any possible orographic effects into account.

\subsection{Pennisetum foermerianum- Ficus ilicina association}

\section{Synopsis:}

Number of relevés: 6

Number of species observed: 97

Estimated number of species: 161

Average species density per $1000 \mathrm{~m}^{2}: 23$

Diagnostic species: Ficus ilicina, Pennisetum foermerianum, Steganotaenia araliacea var. araliacea, Bulbostylis hispidula, Hermannia tigrensis, Datura inoxia, Cyphostemma hereroense, Calostephane divaricata, Eragrostis porosa, Sporobolus fimbriatus, Boscia albitrunca, Cheilanthes marlothii, Ozoroa crassinervia, Pupalia lappacea

Constant species: Tarchonanthus camphoratus, Searsia marlothii, Combretum apiculatum subsp. apiculatum, Triraphis ramosissima, Melinis repens subsp. grandiflora, Enneapogon cenchroides, Senegalia hereroensis

This association is difficult to assign to a structural type, as the vertical dimension is dominated by the habitat, being near-vertical rock faces (Figures 6B and 7B). Most woody species have a shrub-like habit, making it essentially a short, semi-open shrubland. However, e.g. Ozoroa crassinervia grows to a distinct tree. This association occurs on steep rock faces throughout the central Khomas Hochland. Kellner (1986) includes this in his Pennisetum foermerianum-Dombeya rotundifolia association, even though it is, based on its habitat and species composition, distinctly different. Due to the low sampling density and inherent variability it is not described formally.

\subsection{Eriocephalo dinteri-Danthoniopietum ramosae ass. nov.}

\section{Synopsis:}

Number of relevés: 8
Type relevé: 9595 (holotype)

Number of species observed: 69

Estimated number of species: 93

Average species density per $1000 \mathrm{~m}^{2}: 27$

Diagnostic species: Jamesbrittenia pallida, Selago alopecuroides, Eriocephalus dinteri, Frankenia pomonensis, Senecio inaequidens, Cheilanthes hirta, Leucas glabrata, Hypoestes forskaolii, Namacodon schinzianum, Danthoniopsis ramosa, Lepidium africanum, Kalanchoe species

Constant species: Digitaria eriantha, Oxalis purpurascens, Tarchonanthus camphoratus, Eragrostis scopelophila, Eragrostis nindensis

These short, closed grasslands have a dense cover of perennial grasses like Digitaria eriantha, Eragrostis scopelophila, Danthoniopsis ramosa and Andropogon chinensis (Figure 6C). Scattered Tarchonanthus camphoratus and Senegalia hereroensis shrubs also occur. This association occurs on the very steep ( $>60 \%$ ) southern slopes of the Auas Mountain range, at altitudes from $2150 \mathrm{~m}$ asl upwards (Burke \& Wittneben 2007; Strohbach 2017). MAP is about $350 \mathrm{~mm}$ (Mendelsohn et al. 2002), again not taking any orographic effects into account.

\subsection{Danthoniopio ramosae- Oleoetum africanae ass. nov.}

\section{Synopsis:}

Number of relevés: 8

Type relevé: 9592 (holotype), sampled on 13 March 2004 at $22^{\circ} 37^{\prime} 05^{\prime \prime} S, 17^{\circ} 13^{\prime} 14^{\prime \prime} \mathrm{E}$

Number of species observed: 122

Estimated number of species: 151

Average species density per $1000 \mathrm{~m}^{2}: 63$

Diagnostic species: Selago angustibractea, Lopholaena cneorifolia, Cheilanthes multifida, Calostephane marlothiana, Adromischus species, Monsonia burkeana, Anthospermum rigidum, Hypoxis iridifolia, Eriocephalus scariosus, Babiana hypogea, Brachiaria serrata, Diospyros ramulosa, Thesium lacinulatum, Wahlenbergia denticulata, Ebracteola montis-moltkei, Tristachya superba, Silene burchellii var. burchellii, Helichrysum obtusum, Felicia muricata, Olea europaea subsp. africana, Polygala uncinata, Cineraria canescens, Cymbopogon caesius, Kalanchoe brachyloba, Stoebe plumosa, Osteospermum montanum, Leonotis ocymifolia, Anthospermum species, Osyris lanceolata, Searsia tenuinervis, Pegolettia retrofracta, Sida ovata, Dicoma anomala, Danthoniopsis ramosa, Ipomoea obscura var. obscura, Sphedamnocarpus pruriens subsp. pruriens, Fockea angustifolia, Hypoestes forskaolii, Themeda triandra, Ornithoglossum 

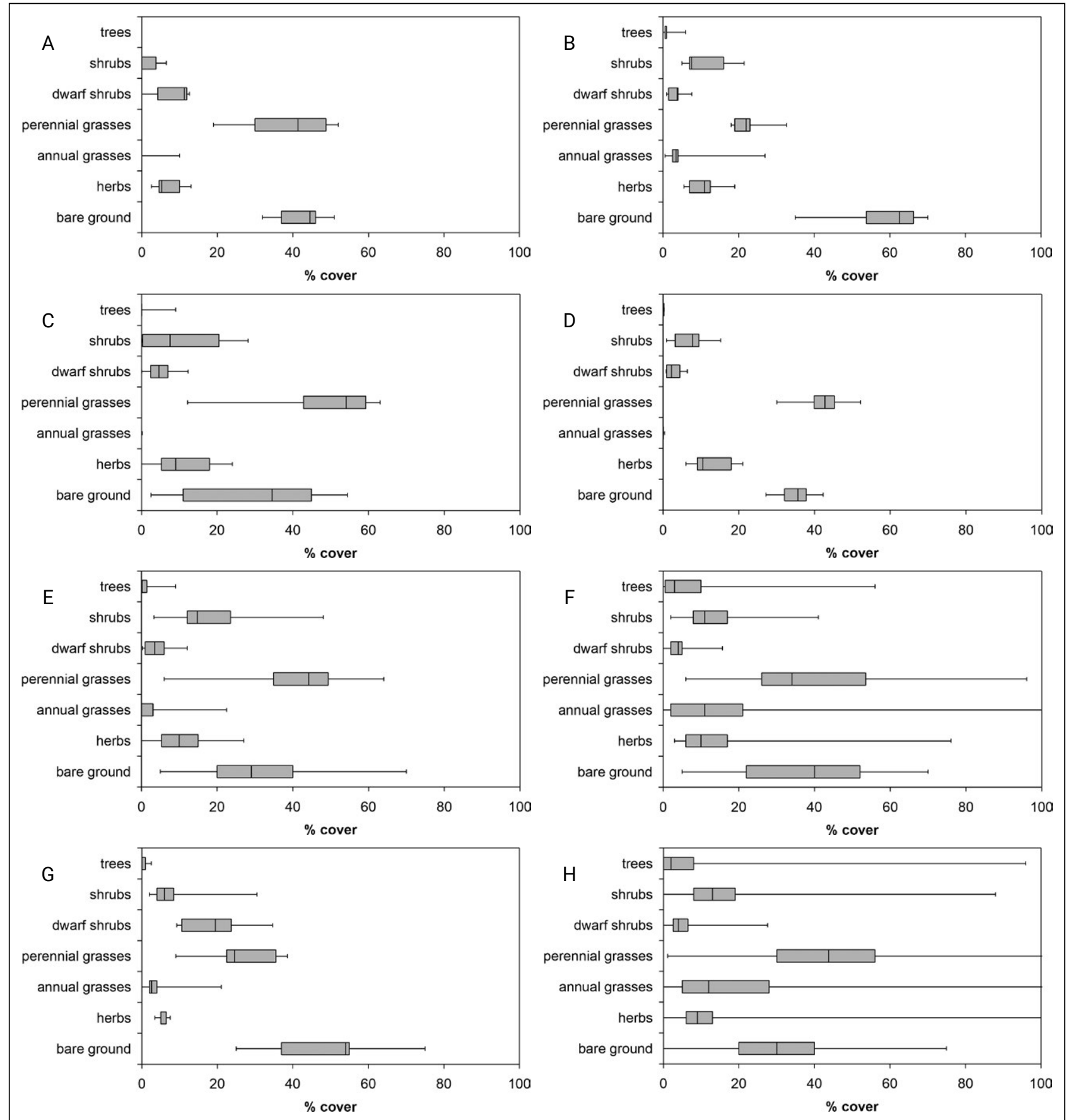

Figure 6. Box-and-Whisker plots of the typical structure of the associations of the Khomas Hochland Proper, based on the relevé data. A, Digitario erianthae-Euryopietum walterorum; B, Pennisetum foermerianum-Ficus ilicina association; C, Eriocephalo dinteri-Danthoniopietum ramosae; D, Danthoniopio ramosae-Oleoetum africanae; E, Senegalio hereroensis-Tarchonanthoetum camphorati; $\mathrm{F}$, Triraphio ramosissimae-Manuleopsietum dinteri; G, Ornithoglosso calcicolae-Fingerhuthioetum africanae; $\mathrm{H}$, Brachiario nigropedatae-Senegalietum hereroensis.

vulgare, Gladiolus saccatus, Rhynchosia totta, Cymbopogon pospischilii, Andropogon chinensis, Jamesbrittenia lyperioides, Crassula capitella, Cotyledon orbiculata, Gymnosporia buxifolia, Ocimum americanum var. americanum, Moraea polystachya, Hebenstretia integrifolia, Cyperus margaritaceus, Boophone disticha, Gladiolus permeabilis subsp. edulis, Euphorbia spartaria, Aptosimum lineare, Hibiscus trionum, Heliophila carnosa, Solanum delagoense, Jamesbrittenia huillana
Constant species: Digitaria eriantha, Senegalia hereroensis, Tarchonanthus camphoratus, Oxalis purpurascens, Eragrostis nindensis, Pellaea calomelanos, Eragrostis scopelophila, Chascanum pinnatifidum, Searsia marlothii, Melinis repens subsp. repens, Heteromorpha arborescens, Commelina africana

This association is best described as a short, closed grassland dominated by Danthoniopsis ramosa and Heteropogon contortus, with some sparse shrub cover. 
Shrubs also occur only on the lower reaches, whilst the mountain tops are distinctly grass covered (Figures $6 \mathrm{D}$ and $7 \mathrm{C}$ ). It occurs on the northern face of the Auas Mountain range at an altitudinal range of $2200 \mathrm{~m}$ asl and above (Burke \& Wittneben 2007; Strohbach 2017). The soil surface is rock-strewn, with quarzite boulders and solid rock of the Auas formation (Geological Survey 1980; South African Committee for Stratigraphy 1980). MAP is between 350 and $400 \mathrm{~mm}$, without taking any orographic effects into account.

\subsection{Senegalio hereroensis- Tarchonanthoetum camphorati ass. nov.}

\section{Synopsis:}

Number of relevés: 22

Type relevé: 1123 (holotype), sampled on 25 April 2002 at $22^{\circ} 48^{\prime} 34^{\prime \prime} \mathrm{S}, 17^{\circ} 02^{\prime} 00^{\prime \prime} \mathrm{E}$

Number of species observed: 171

Estimated number of species: 237

Average species density per $1000 \mathrm{~m}^{2}: 43$

Diagnostic species: Sida chrysantha, Phyllanthus species, Brachiaria nigropedata, Dyschoriste pseuderecta

Constant species: Senegalia hereroensis, Tarchonanthus camphoratus, Pellaea calomelanos, Melinis repens subsp. repens, Heteropogon contortus, Eragrostis scopelophila, Eragrostis nindensis, Digitaria eriantha, Searsia marlothii, Hypoestes forskaolii

This tall, semi-open shrubland is dominated by Tarchonanthus camphoratus, Searsia marlothii and Senegalia hereroensis, with the grasses Brachiaria nigropedata, Eragrostis scopelophila and Digitaria eriantha dominating the grass layer (Figures 6E and 7D). This association occurs on the Auas Mountain and Lichtenstein ranges at mid-altitude, between 2000 and $2300 \mathrm{~m}$ asl. No evidence could be found for a differentiation between north- and south-facing sides of the mountains, unlike reported by Burke and Wittneben (2007) or Strohbach (2017). These slopes are steep (30-60\%) with considerable quartzite stone cover, especially medium to large stones, even rocks ( $\pm 80 \%$ stone and rock cover), of the Auas formation.

\subsection{Triraphio ramosissimae- Manuleopsietum dinteri ass. nov.}

\section{Synopsis:}

Number of relevés: 53

Type relevé: 1011 (holotype), sampled on 16 March 2000 at $22^{\circ} 46^{\prime} 43^{\prime \prime} \mathrm{S}, 16^{\circ} 46^{\prime} 41^{\prime \prime} \mathrm{E}$

Number of species observed: 170

Estimated number of species: 258

Average species density per $1000 \mathrm{~m}^{2}: 32$
Diagnostic species: Pennisetum foermerianum, Triraphis ramosissima

Constant species: Cheilanthes marlothii, Searsia marlothii, Cenchrus ciliaris, Melinis repens subsp. grandiflora, Eragrostis nindensis, Enneapogon cenchroides, Anthephora pubescens, Stipagrostis uniplumis var. uniplumis

Typical for this short, semi-open shrubland are trees and shrubs of Combretum apiculatum subsp. apiculatum, Ozoroa crassinervia, Dombeya rotundifolia and occasionally Euphorbia avasmontana, together with other highland savanna species. The grass layer is also dominated by rock-specialists like Pennisetum foermerianum, Triraphis ramosissima, Eragrostis scopelophila and Danthoniopsis ramosa (Figures 6F and 7E). This association occurs on smaller mica-schist rock outcrops common within the central Khomas Hochland, as part of the Kuiseb formation. These are normally between $10 \times 10$ to over $50 \times 50 \mathrm{~m}$ in surface area, but always broken, never solid rock faces. Due to the nature of the rock beds of the Khomas Hochland, many of these rock outcrops face south (but not exclusively). Altitude ranges between 1600 and $1800 \mathrm{~m}$ asl, whilst MAP ranges between 250 and $400 \mathrm{~mm}$.

Kellner (1986) distinguishes two forms of this association, being a Pennisetum foermerianum-Dombeya rotundifolia community on broken rock outcrops, as well as a Triraphis ramosissima-Combretum apiculatum community on more solid, platy rock outcrops, generally also with more gentle slopes. This subdivision was neither confirmed in this study, nor by Strohbach (2017). Volk and Leippert (1971) also describe a Combretum apiculatum-Eragrostis scopelophila association, unfortunately without proper synopsis.

\subsection{Ornithoglosso calcicolae- Fingerhuthioetum africanae ass. nov.}

\section{Synopsis:}

Number of relevés: 9

Type relevé: 1095 (holotype), sampled on 23 April 2002 at $22^{\circ} 58^{\prime} 29^{\prime \prime} \mathrm{S}, 17^{\circ} 07^{\prime} 00^{\prime \prime} \mathrm{E}$

Number of species observed: 98

Estimated number of species: 136

Average species density per $1000 \mathrm{~m}^{2}: 37$

Diagnostic species: Ornithoglossum calcicola, Melhania damarana, Monechma genistifolium, Zygophyllum pubescens, Cleome suffruticosa, Stipagrostis hirtigluma, Enneapogon desvauxii, Otoptera burchellii, Leucosphaera bainesii, Euphorbia lignosa, Crotalaria kurtii, Blepharis mitrata, Enneapogon scoparius, Stipagrostis ciliata, Polygala pallida, Fingerhuthia africana, Sericorema sericea, Polygala leptophylla, Thesium xerophyticum, Seidelia 

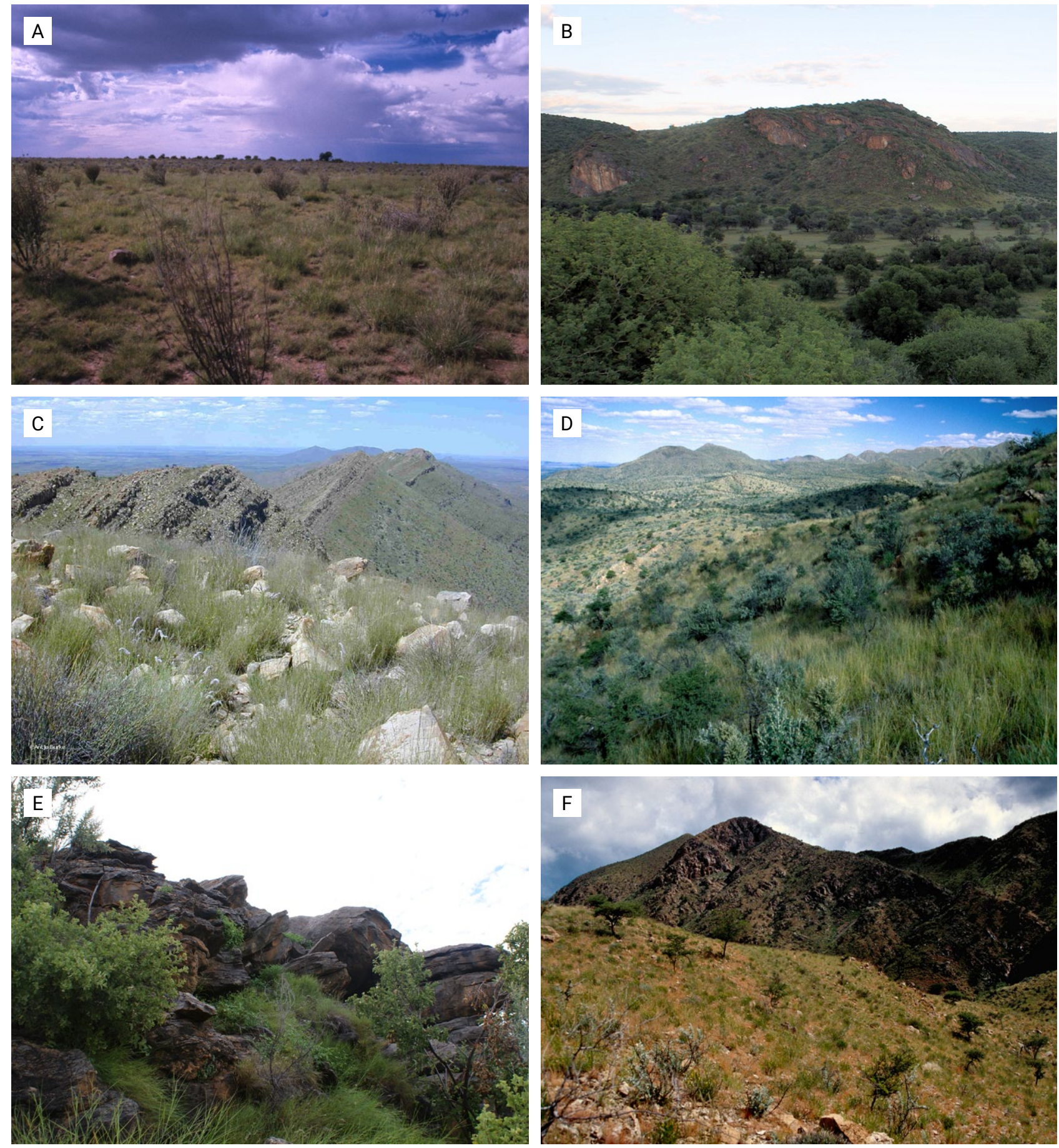

G

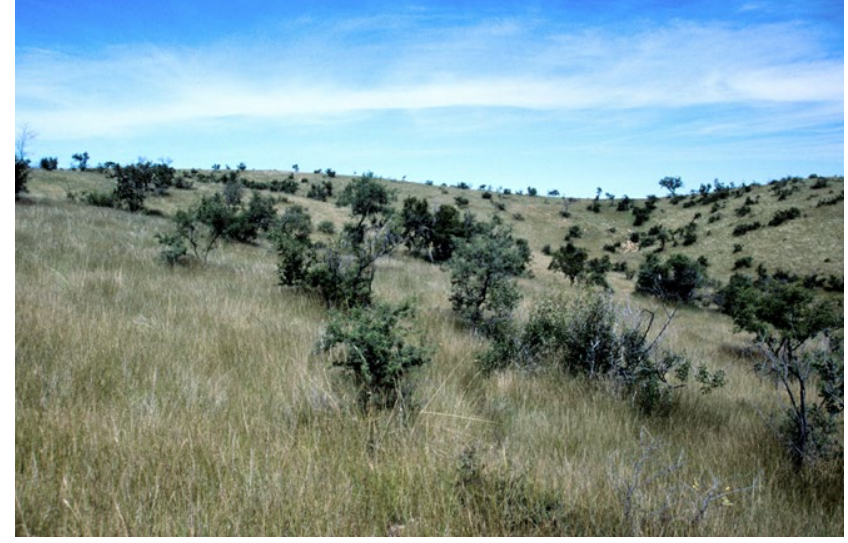

Figure 7. Typical views of the associations of the Khomas Hochland Proper. A, Digitario erianthae-Euryopietum walterorum, relevé 1837; B, Examples of rock faces hosting the Pennisetum foermerianum-Ficus ilicina association, here at Midgard; C, Danthoniopio ramosae-Oleoetum africanae on top of the Auas Mountains; D, Senegalio hereroensis-Tarchonanthoetum camphorati, relevé 1123; E, Triraphio ramosissimae-Manuleopsietum dinteri, relevé 1011; F, Ornithoglosso calcicolae-Fingerhuthioetum africanae, relevé 1095; G, Brachiario nigropedatae-Senegalietum hereroensis, relevé 1003. Photos: $\mathrm{C}$ by Dr Antje Burke, remainder by the author. 
firmula, Sarcostemma viminale, Senegalia mellifera subsp. detinens, Hermannia abrotanoides, Eriocephalus luederitzianus, Croton gratissimus, Grewia flava, Aizoon virgatum, Catophractes alexandri, Monelytrum luederitzianum, Helinus spartioides, Pentzia monocephala, Justicia guerkeana, Barleria lancifolia, Aristida effusa, Pelargonium otaviense, Eragrostis echinochloidea

Constant species: Searsia marlothii, Senegalia hereroensis, Eragrostis nindensis, Enneapogon cenchroides, Talinum caffrum

This short, semi-open shrubland is dominated by the dwarf shrub Monechma genistifolium and the grass Fingerhuthia africana (Figures 6G and 7F). The occasional occurrence of Senegalia hereroensis indicates the relationship to the central Khomas Hochland. This association occurs on the slopes of the Oamites Mountain, which is made up of grey quartzite and sericite phyllite of the Billstein formation (Geological Survey 1980; South African Committee for Stratigraphy 1980). The steep to very steep slopes are covered with rocks (up to $40 \%$ ) and a mixture of small, medium and large stones (combined over $40 \%$ ), at an altitudinal range of between 1700 and $1800 \mathrm{~m}$ asl, and a MAP of $350 \mathrm{~mm}$.

\subsection{Brachiario nigropedatae- Senegalietum hereroensis ass. nov.}

\section{Synopsis:}

Number of relevés: 238

Type relevé: 1003 (holotype), sampled on 16 March 2000 at $22^{\circ} 49^{\prime} 33^{\prime \prime} \mathrm{S}, 16^{\circ} 50^{\prime} 00^{\prime \prime} \mathrm{E}$

Number of species observed: 287

Estimated number of species: 403

Average species density per $1000 \mathrm{~m}^{2}: 36$

Diagnostic species: Aristida meridionalis, Gnidia polycephala, Schmidtia pappophoroides, Eragrostis superba, Pogonarthria fleckii

Constant species: Senegalia hereroensis, Eragrostis nindensis, Anthephora pubescens, Searsia marlothii, Melinis repens subsp. grandiflora, Brachiaria nigropedata, Stipagrostis uniplumis var. uniplumis, Monelytrum luederitzianum, Enneapogon cenchroides, Ziziphus mucronata, Cenchrus ciliaris

These short, semi-open bushlands are dominated by shrubs of Senegalia hereroensis, with scattered low trees and shrubs of Tarchonanthus camphoratus, Ziziphus mucronata, Combretum apiculatum subsp. apiculatum, Senegalia mellifera subsp. detinens, Euclea undulata, Vachellia tortilis, Albizia anthelmintica and Vachellia reficiens. The grass layer is rather species-rich, with Eragrostis nindensis, Enneapogon cenchroides, Monelytrum luederitzianum, Aristida adscensionis, Cenchrus ciliaris, Brachiaria nigropedata, Aristida meridionalis, Melinis repens subsp. grandiflora, Anthephora pubescens, Triraphis ramosissima and Stipagrostis uniplumis var. uniplumis being the dominating species (Figures $6 \mathrm{H}$ and 7G). The veld of the central Khomas Hochland occurs on moderately steep to steep hills and mountains with shallow ( $<30 \mathrm{~cm}$ deep) soils on mica schists of the Kuiseb Formation (Geological Survey 1980, Schneider 2004). The stone cover is dominated by pebbles and medium-sized quartz stones up to $40 \%$, with only occasional sub-outcropping mica schists. This association is the most extensive association within the central Khomas Hochland and occurs at an altitude of between 1600 and $2000 \mathrm{~m}$ asl. MAP ranges between 200 and nearly $400 \mathrm{~mm}$.

\section{Riverine vegetation}

The vegetation of the riverine habitats is dominated by the plant families Poaceae, Asteraceae, Fabaceae and Amaranthaceae. The classification resulted in seven associations, which are formally described according to the International Code of Phytosociological Nomenclature (Weber et al. 2000) below. The synoptic table for these is presented in online Appendix 1, and the phytosociological table in online Appendix 2.

\subsection{Eragrostio rotiferi-Oleoetum africanae ass. nov.}

\section{Synopsis:}

Number of relevés: 3

Type relevé: 11525 (holotype), sampled on 16 April 2014 at $22^{\circ} 08^{\prime} 04^{\prime \prime}$ S, $17^{\circ} 17^{\prime} 45^{\prime \prime} \mathrm{E}$

Number of species observed: 51

Estimated number of species: 66

Average species density per $1000 \mathrm{~m}^{2}: 34$

Diagnostic species: Olea europaea subsp. africana, Brachylaena huillensis, Diospyros lycioides, Oxalis purpurascens, Searsia lancea, Alternanthera nodiflora, Digitaria eriantha, Kohautia azurea, Gladiolus permeabilis subsp. edulis, Crassula capitella, Commelina subulata, Cymbopogon pospischilii

Constant species: Ziziphus mucronata, Tagetes minuta, Eragrostis rotifer, Commelina benghalensis, Chloris virgata, Bidens biternata, Sporobolus fimbriatus, Setaria verticillata, Schoenoplectus muricinux, Pogonarthria fleckii, Panicum maximum, Oxygonum alatum, Melinis repens subsp. grandiflora, Eragrostis superba, Eragrostis lehmanniana, Eragrostis echinochloidea, Dactyloctenium aegyptium, Asparagus nelsii, Achyranthes aspera, Vachellia karroo

These short, moderately closed woodlands occur in narrow, steep-sided ravines in the Khomas Hochland, 
forming the headwaters of the rivers. The riverbed is not well-developed, often formed by boulders and eroded rock crevices and is generally overgrown (Figures $8 \mathrm{~A}$ and $9 \mathrm{~A}$ ). Due to the narrowness of this bed, it was sampled with the banks. Rock cover is up to $40 \%$, with considerable small, medium and large stone cover as well. Due to the relatively small sample, no reliable indication is available on the distribution, altitudinal range or MAP. The sampled relevés range between 1780 and $1800 \mathrm{~m}$ asl, at a MAP of $350 \mathrm{~mm}$.

\subsection{Cynodo dactylonis-Eragrostioetum rotiferi ass. nov.}

\section{Synopsis:}

Number of relevés: 17

Type relevé: 11520 (holotype), sampled on 16 April 2014 at $22^{\circ} 06^{\prime} 36^{\prime \prime} \mathrm{S}, 17^{\circ} 17^{\prime} 40^{\prime \prime} \mathrm{E}$

Number of species observed: 79

Estimated number of species: 148

Average species density per $1000 \mathrm{~m}^{2}: 18$

Diagnostic species: Hyparrhenia hirta, Gomphostigma virgatum, Datura inoxia, Eragrostis rotifer

Constant species: Chloris virgata, Eragrostis echinochloidea, Cynodon dactylon, Cenchrus ciliaris, Eragrostis superba, Bidens biternata, Tagetes minuta, Melinis repens subsp. grandiflora

As the rivers widen, a distinct near-flat, coarse sandy bed is formed, on which this sparse short grassland establishes (Figures 8B and 9B). Depending on the flow regime (fast- or slow flowing, or even standing or seepage areas), a variety of species establish, often of ephemeral nature. Generally, Chloris virgata, Sporobolus fimbriatus, Eragrostis rotifer, Eragrostis omahekensis, Eragrostis echinochloidea and Cynodon dactylon dominate this association. This association occurs widespread in the study area as important part of the drainage system.

\subsection{Stipagrostioetum} namaquensis ass. nov.

\section{Synopsis:}

Number of relevés: 4

Type relevé: 973 (holotype), sampled on 20 April 2000 at $22^{\circ} 49^{\prime} 08^{\prime \prime} \mathrm{S}, 16^{\circ} 49^{\prime} 36^{\prime \prime} \mathrm{E}$

Number of species observed: 61

Estimated number of species: 83

Average species density per $1000 \mathrm{~m}^{2}: 30$

\section{Diagnostic species: Felicia clavipilosa, Stipagrostis na- maquensis, Oxygonum alatum}

Constant species: Pogonarthria fleckii, Acrotome fleckii, Tragus racemosus, Tagetes minuta, Melinis repens subsp. grandiflora, Melianthus comosus, Kyllinga alata, Galenia africana, Enneapogon cenchroides, Chloris virgata, Bulbostylis hispidula, Bidens biternata, Vachellia karroo, Tetragonia calycina, Stachys spathulata, Schmidtia kalahariensis, Schkuhria pinnata, Ocimum americanum var. americanum, Monechma spartioides, Limeum sulcatum, Indigofera alternans, Hermbstaedtia odorata, Heliotropium nelsonii, Geigeria pectidea, Eragrostis trichophora, Eragrostis porosa, Eragrostis omahekensis, Cucumis africanus, Cenchrus ciliaris, Anthephora schinzii, Anthephora pubescens, Amaranthus thunbergii, Achyranthes aspera var. sicula

Larger rivers in relatively low-gradient environments (e.g. the Oanob) form deep sandbanks adjacent to the main flow channels, on which this tall, moderately closed grassland occurs (Figures 8C and 9C). Unlike the Cynodo dactylonis-Eragrostioetum rotiferi, this association is of more permanent nature, with Stipagrostis namaquensis stabilising the sand bank, and allowing sedimentation on this sand bank. This eco-engineer also forms a suitable habitat for phanerophytic species (commonly Vachellia karroo, but also Vachellia erioloba, Faidherbia albida and Euclea pseudebenus) to establish. The sandbanks found in the Oanob River form the western-most occurrence of this association, with extensive sandbanks found further east in the Seeis and Nossob river systems. These sand banks occur within the study area at an altitude of between 1850 and $1950 \mathrm{~m}$ asl, and a MAP of between 300 and $350 \mathrm{~mm}$.

\subsection{Themedio triandrae-Chloroetum virgatae ass. nov.}

\section{Synopsis:}

Number of relevés: 8

Type relevé: 939 (holotype), sampled on 10 April 2000 at $22^{\circ} 45^{\prime} 24^{\prime \prime} \mathrm{S}, 16^{\circ} 52^{\prime} 28^{\prime \prime} \mathrm{E}$

Number of species observed: 130

Estimated number of species: 185

Average species density per $1000 \mathrm{~m}^{2}: 42$

Diagnostic species: Tragus berteronianus, Schmidtia pappophoroides, Themeda triandra, Talinum caffrum, Platycarphella carlinoides, Monsonia angustifolia, Microchloa caffra, Eragrostis superba, Geigeria pectidea

Constant species: Chloris virgata, Eragrostis porosa, Eragrostis echinochloidea, Anthephora pubescens, Vachellia karroo, Ursinia nana, Tribulus zeyheri, Kyllinga alata, Heliotropium nelsonii, Eragrostis nindensis, Aristida congesta subsp. congesta, Vachellia erioloba, Urochloa brachyura, Tragus racemosus, Tetragonia calycina, Schkuhria pinnata, Pogonarthria fleckii, Lycium bosciifolium, Limeum sulcatum, Eragrostis trichophora, Eragrostis rotifer, Enneapogon cenchroides, Cymbopogon pospischilii, Cenchrus ciliaris, Acrotome fleckii 
In the low-gradient landscape of the Oanob Plateau, but also other low-gradient areas like the Regenstein Valley and at Neudamm, valleys have been filled with sediments, forming a low-gradient, overgrown emphemeral wetland locally referred to as an omuramba (plural - omirimbi) (King 1963, Strohbach 2008). This forms the habitat for the Themedio triandrae-Chloroetum virgatae, a short, moderately-closed grassland (Figures 8D and 9D), dominated by ephemeral species like Geigeria pectidea, Tribulus terrestris, Chloris virgata, Aristida hordeacea and Aristida adscensionis. Only Aristida congesta subsp. congesta is a prominent perennial species, whilst the name-giving Themeda triandra is a rare species, often only occurring as remnant of the original lush grassland described by Volk and Leippert (1971). These authors already noted the generally poor state of this vegetation, which is prone to degradation and erosion. Once erosion sets in, the sediments are soon washed away to form a low-productive riverbed similar to the Cynodo dactylonis-Eragrostioetum rotiferi, with shrubs and trees establishing on the sides to form the start of the Chloro virgatae-Vachellietum karroo. The Themedio triandrae-Chloroetum virgatae occurs at an altitudinal range of between 1740 and $2200 \mathrm{~m}$ asl, and at a MAP of between 300 and $400 \mathrm{~mm}$.

\subsection{Chloro virgatae-Vachellietum karroo ass. nov.}

\section{Synopsis:}

Number of relevés: 37

Type relevé: 11519 (holotype), sampled on 16 April 2014 at $22^{\circ} 06^{\prime} 35^{\prime \prime} \mathrm{S}, 17^{\circ} 17^{\prime} 40^{\prime \prime} \mathrm{E}$

Number of species observed: 218

Estimated number of species: 312

Average species density per $1000 \mathrm{~m}^{2}: 26$

Diagnostic species: Senegalia mellifera subsp. detinens, Phaeoptilum spinosum, Grewia flava, Aristida adscensionis, Eragrostis rigidior, Monechma divaricatum

Constant species: Vachellia karroo, Eragrostis porosa, Enneapogon cenchroides, Eragrostis echinochloidea, Ziziphus mucronata, Cenchrus ciliaris, Vachellia erioloba, Chloris virgata, Stipagrostis uniplumis var. uniplumis, Pogonarthria fleckii, Melinis repens subsp. grandiflora, Aristida congesta subsp. congesta, Bidens biternata

These tall, closed thickets are dominated by the tree and shrub species Vachellia karroo, Vachellia tortilis, Senegalia mellifera subsp. detinens and Ziziphus mucronata (Figures $8 \mathrm{E}$ and $9 \mathrm{E}$ ). The herb layer consists of a mixture of various species, often shade tolerant species. The Chloro virgatae-Vachellietum karroo form the riparian forests lining most major inland rivers in the Khomas Hochland and have strong affinities to the Ziziphus mucronata-Acacia tortilis association described for the Thornbush savanna (Strohbach 2019). Both Kellner
(1986) and Strohbach (2017) refer to the Chloro virgatae-Vachellietum karroo as Cynodon dactylon-Acacia karroo association, a name which was rejected as the name-giving Cynodon dactylon was neither a diagnostic nor constant species in this association.

The Chloro virgatae-Vachellietum karroo generally have a steep bank towards the riverbed but are fairly flat beyond the bank. Stone cover is low, rather occasional, mostly deposited by extreme flood events. This association occurs at altitudes of between 1540 and $1950 \mathrm{~m}$ asl, and MAP of between 250 and $400 \mathrm{~mm}$.

\subsection{Salvadoro persicae-Eucleetum pseudebeno ass. nov.}

\section{Synopsis:}

Number of relevés: 5

Type relevé: 1929 (holotype), sampled on 16 February 2004 at $23^{\circ} 10^{\prime} 21^{\prime \prime} \mathrm{S}, 16^{\circ} 02^{\prime} 28^{\prime \prime} \mathrm{E}$

Number of species observed: 48

Estimated number of species: 66

Average species density per $1000 \mathrm{~m}^{2}: 21$

\section{Diagnostic species: Stipagrostis hochstetteriana, Eu- clea pseudebenus, Salvadora persica, Tribulus zeyheri, Portulaca oleracea}

Constant species: Cenchrus ciliaris, Vachellia erioloba, Ziziphus mucronata, Pergularia daemia, Heliotropium nelsonii, Gisekia africana, Faidherbia albida, Amaranthus thunbergii

The Salvadoro persicae-Eucleetum pseudebeno forms a tall, semi-open woodland dominated by Faidherbia albida and Salvadora persica (Figures $8 \mathrm{~F}$ and 9F). This association form the riparian forests along the bigger rivers in the western (Pre-Namib) part of the study area, i.e. the middle reaches of the Swakop, Kuiseb and Gaub rivers. The relationship to the lower Kuiseb vegetation (Theron et al. 1980) needs to be investigated further.

The Salvadoro persicae-Eucleetum pseudebeno occurs in the lower rainfall areas, with a MAP of less than $200 \mathrm{~mm}$, and at altitudes less than $1100 \mathrm{~m}$ asl. Similar to its inland equivalents (the Chloro virgatae-Vachellietum karroo and the Setario finitae-Vachellietum eriolobae), this association displays low slope gradients (flat to gently undulating) with little stone cover.

\subsection{Setario finitae-Vachellietum eriolobae ass. nov.}

\section{Synopsis:}

Number of relevés: 18

Type relevé: 11488 (holotype), sampled on 30 March 2014 at $22^{\circ} 02^{\prime} 29^{\prime \prime} \mathrm{S}, 17^{\circ} 22^{\prime} 08^{\prime \prime} \mathrm{E}$

Number of species observed: 69 

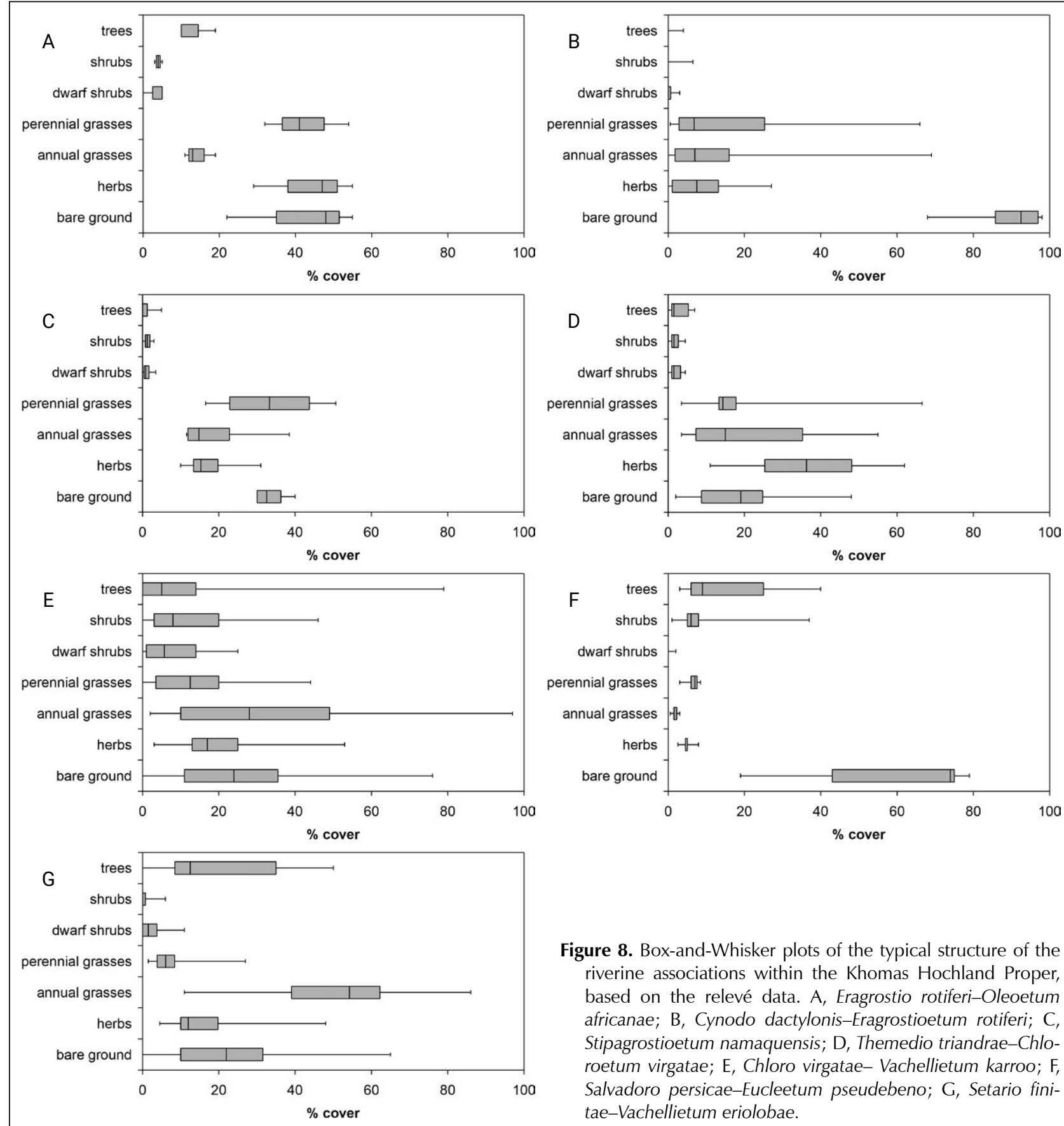

Figure 8. Box-and-Whisker plots of the typical structure of the riverine associations within the Khomas Hochland Proper, based on the relevé data. A, Eragrostio rotiferi-Oleoetum africanae; B, Cynodo dactylonis-Eragrostioetum rotiferi; C, Stipagrostioetum namaquensis; D, Themedio triandrae-Chloroetum virgatae; $\mathrm{E}$, Chloro virgatae- Vachellietum karroo; $\mathrm{F}$, Salvadoro persicae-Eucleetum pseudebeno; G, Setario finitae-Vachellietum eriolobae.

Estimated number of species: 101

Average species density per $1000 \mathrm{~m}^{2}: 25$

Diagnostic species: Setaria finita, Eragrostis cilianensis, Digitaria velutina, Zehneria marlothii, Chenopodium petiolariforme, Cyperus squarrosus, Sporobolus fimbriatus, Urochloa brachyura, Solanum delagoense, Cucumis meeusei, Schmidtia kalahariensis, Pechuel-Loeschea leubnitziae

Constant species: Bidens biternata, Pogonarthria fleckii, Chloris virgata, Vachellia erioloba, Ziziphus mucronata, Schkuhria pinnata, Cenchrus ciliaris, Bulbostylis hispidula, Vachellia karroo, Setaria verticillata,
Eragrostis echinochloidea, Tagetes minuta, Eragrostis trichophora, Dactyloctenium aegyptium, Anthephora schinzii, Amaranthus thunbergii

This tall, moderately closed woodland is found along the banks of the big inland rivers of the Khomas Hochland, notably the upper reaches of the Swakop River, but also its tributaries like the Gammams and Otjiseva rivers (Figures 8G and 9G). It is dominated by Ziziphus mucronata, Vachellia karroo and Vachellia erioloba trees, with Faidherbia albida also occurring occasionally.

The Setario finitae-Vachellietum eriolobae often forms islands within broad riverbeds, indicating a relationship, 

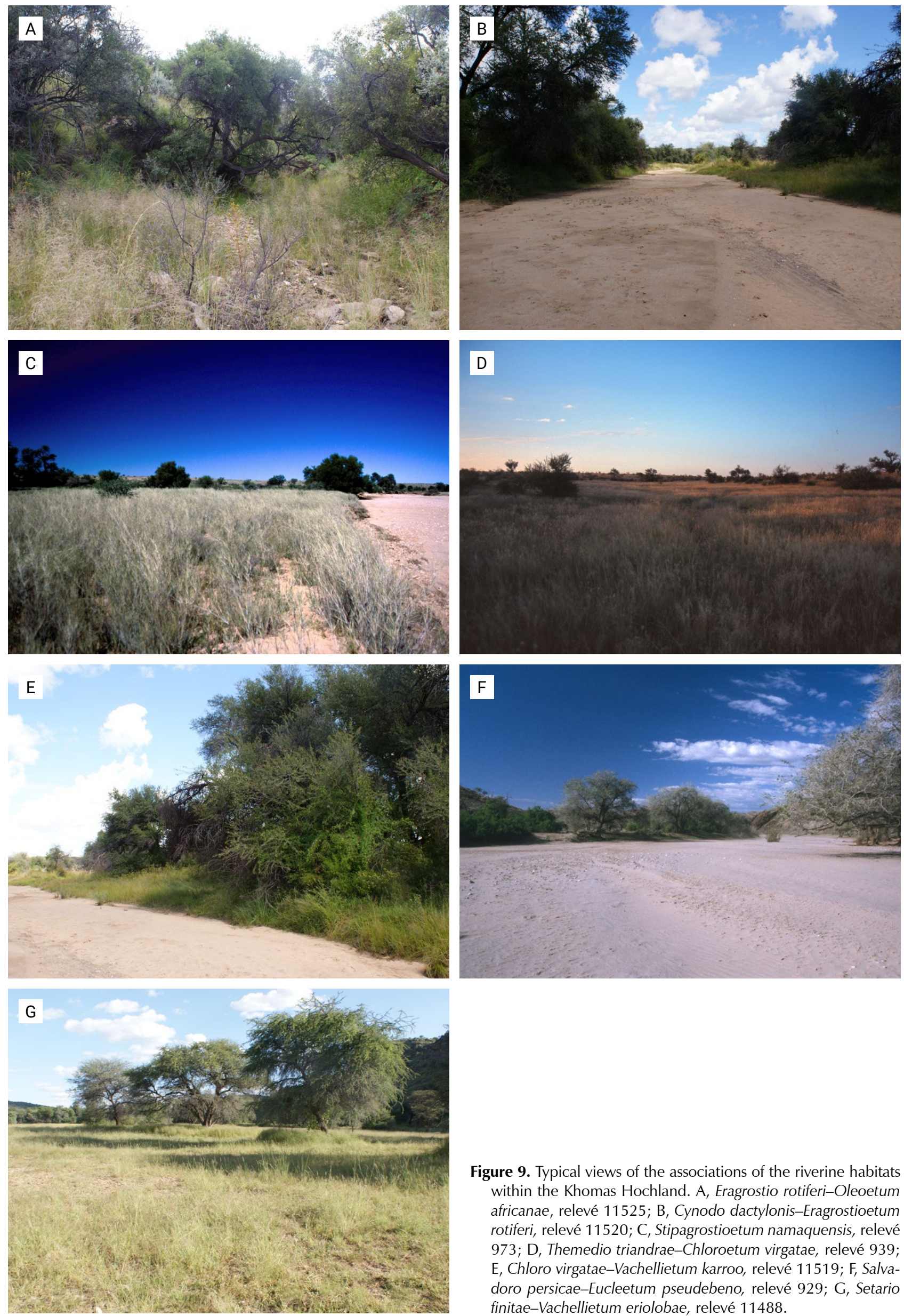

Figure 9. Typical views of the associations of the riverine habitats within the Khomas Hochland. A, Eragrostio rotiferi-Oleoetum africanae, relevé 11525; B, Cynodo dactylonis-Eragrostioetum rotiferi, relevé 11520; C, Stipagrostioetum namaquensis, relevé 973; D, Themedio triandrae-Chloroetum virgatae, relevé 939; E, Chloro virgatae-Vachellietum karroo, relevé 11519; F, Salvadoro persicae-Eucleetum pseudebeno, relevé 929; G, Setario finitae-Vachellietum eriolobae, relevé 11488. 
possibly even a successional advanced stage, of the Stipagrostietum namaquensis. It has been found at altitudes of between 1550 and $1600 \mathrm{~m}$ asl, and MAP range of between 300 and $400 \mathrm{~mm}$.

\section{Lowlands surrounding the Khomas Hochland}

The vegetation of the surrounding lowlands is dominated by the plant families Poaceae, Fabaceae, Asteraceae and Amaranthaceae. Eight associations, one with four sub-associations, were identified and are formally described following guidelines of the ICPN below (with one exception). Their composition is presented in Appendices 1 and 2 as synoptic and phytosociological tables.

\subsection{Pseudogaltonio clavatae- Eriocephaloetum luederitziana ass. nov.}

\section{Synopsis:}

Number of relevés: 35

Type relevé: 10624 (holotype), sampled on 18 April

2011 at $23^{\circ} 07^{\prime} 18^{\prime \prime} \mathrm{S}, 16^{\circ} 54^{\prime} 00^{\prime \prime} \mathrm{E}$

Number of species observed: 131

Estimated number of species: 217

Average species density per $1000 \mathrm{~m}^{2}: 37$

Diagnostic species: Stipagrostis obtusa, Senecio windhoekensis, Rosenia humilis, Sporobolus nervosus, Enneapogon desvauxii, Sida ovata, Polygala pallida, Aizoon schellenbergii, Pentzia calva, Sericorema sericea, Eragrostis echinochloidea, Melhania virescens, Pseudogaltonia clavata, Aptosimum lineare, Leobordea platycarpa, Pteronia mucronata

Constant species: Leucosphaera bainesii, Stipagrostis uniplumis var. uniplumis, Hirpicium gazanioides, Eragrostis nindensis, Eriocephalus luederitzianus, Fingerhuthia africana, Cenchrus ciliaris, Stipagrostis ciliata, Eragrostis porosa, Melinis repens subsp. grandiflora, Hermannia modesta, Barleria rigida, Vachellia erioloba, Tribulus zeyheri, Pogonarthria fleckii, Enneapogon cenchroides

This low, moderately closed shrubland has a distinct karoid character, being dominated by the dwarf shrub species Eriocephalus luederitzianus, Monechma genistifolium, Leucosphaera bainesii and Aizoon schellenbergii (Figures 10A and 11A). This association is limited to the Narais plains towards Rehoboth, occurring on shallow loamy soils on calcretes, which have formed over the quarzites of the Duruchaus formation. Stone cover is about $20 \%$, mostly calcrete gravel and small stones. Occasional deep pockets in the subsurfacing calcretes allow Vachellia erioloba trees to establish, adding a very sparse tree layer to this association's structure (Jürgens et al. 2010). This association receives between 250 and $300 \mathrm{~mm}$ MAP and is at an altitudinal range of between 1580 and $1640 \mathrm{~m}$ asl. The topography is generally flat.

\subsection{Panico lanipedis-Pentzietum incanae ass. nov.}

\section{Synopsis:}

Number of relevés: 59

Type relevé: 1020 (holotype), sampled on 17 March 2000 at $22^{\circ} 48^{\prime} 42^{\prime \prime} \mathrm{S}, 16^{\circ} 51^{\prime} 40^{\prime \prime} \mathrm{E}$

Number of species observed: 180

Estimated number of species: 232

Average species density per $1000 \mathrm{~m}^{2}: 52$

Diagnostic species: Panicum lanipes, Blepharis integrifolia, Eriospermum flagelliforme, Plinthus sericeus, Pteronia eenii, Pentzia incana, Ipomoea bolusiana, Talinum caffrum, Monelytrum luederitzianum, Commelina africana, Oxygonum sinuatum, Ursinia nana

Constant species: Eriocephalus Iuederitzianus, Eragrostis nindensis, Senegalia mellifera subsp. detinens, Microchloa caffra, Kyphocarpa angustifolia, Aristida adscensionis, Phaeoptilum spinosum, Hermannia modesta, Leucosphaera bainesii, Chascanum pinnatifidum, Schmidtia pappophoroides, Barleria rigida, Aptosimum spinescens, Melinis repens subsp. grandiflora, Hirpicium gazanioides, Pogonarthria fleckii, Hibiscus discophorus, Tragus berteronianus, Lycium eenii, Catophractes alexandri, Stipagrostis uniplumis var. uniplumis, Ocimum americanum var. americanum, Fingerhuthia africana, Eragrostis porosa, Aristida congesta subsp. congesta, Vachellia hebeclada subsp. hebeclada, Tarchonanthus camphoratus, Platycarphella carlinoides, Enneapogon cenchroides, Geigeria ornativa, Anthephora pubescens, Senegalia hereroensis, Searsia marlothii, Raphionacme velutina, Eragrostis trichophora, Cyperus palmatus

The Panico lanipedis-Pentzietum incanae varies from a low, open to semi-open shrubland to a tall, moderately-closed shrubland, depending on its state of encroachment by savanna species. In its natural state it has a distinct karoid character, being dominated by Leucosphaera bainesii and Eriocephalus luederitzianus (Figures 10B and 11B). This association is however prone to encroachment by specifically Senegalia mellifera subsp. detinens, Catophractes alexandri and/or Vachellia reficiens, which causes the structure to change to a tall, denser shrubland. It occurs specifically on the rolling to moderately steep Oanob plateau, whilst similar vegetation has been also observed on the Hoffnung plateau east of Windhoek as well as at Neu Heusis west of Windhoek. As with the surrounding Brachiario nigropedatae-Senegalietum hereroensis, the subsurface geology are mica schists of the Kuiseb formation. However, the landscape is a gentler, undulating to rolling 
plateau at an altitudinal range of between 1800 and $1900 \mathrm{~m}$ asl. Stone cover is about $40 \%$, mainly by small and medium-sized stones. MAP is between 300 and $350 \mathrm{~mm}$.

\subsection{Aptosimo spinescentis- Galenietum africanae ass. nov.}

\section{Synopsis:}

Number of relevés: 8

Type relevé: 2155 (holotype), sampled on 11 February 2005 at $23^{\circ} 16^{\prime} 25^{\prime \prime} \mathrm{S}, 16^{\circ} 31^{\prime} 06^{\prime \prime} \mathrm{E}$

Number of species observed: 83

Estimated number of species: 136

Average species density per $1000 \mathrm{~m}^{2}: 32$

Diagnostic species: Eriocephalus ericoides, Galenia africana, Geigeria pectidea, Hermannia comosa, Aptosimum spinescens

Constant species: Stipagrostis uniplumis var. uniplumis, Eragrostis porosa, Eragrostis nindensis, Aristida adscensionis, Tribulus terrestris, Platycarphella carlinoides, Phaeoptilum spinosum, Eragrostis echinochloidea, Stipagrostis ciliata, Pentzia calva, Ocimum americanum var. americanum, Kohautia cynanchica, Eriocephalus luederitzianus, Eragrostis lehmanniana, Enneapogon desvauxii, Enneapogon cenchroides, Chascanum pinnatifidum, Aristida congesta subsp. congesta, Aptosimum albomarginatum, Vachellia erioloba

These short, semi-open shrublands are limited to the alluvial plains around the farm Göllschau (H.E.S.S. project) in the southwestern Khomas Hochland (Figures 10C and 11C). The plains are dominated by the grasses Stipagrostis uniplumis var. uniplumis, Aristida adscensionis and Sporobolus nervosus, whilst the dwarf shrubs Eriocephalus ericoides and Galenia africana give it a karoid character. Occasional trees of Vachellia erioloba also occur here. The alluvial soils are derived from granites of the Gamsberg suite, which is sub-outcropping here (less than 5\% cover). Slopes are generally flat to gently undulating, at an altitudinal range of 1750 to $1800 \mathrm{~m}$ asl. MAP is about $250 \mathrm{~mm}$.

\subsection{Panico arbusculi-Senegalietum detinentis ass. nov.}

\section{Synopsis:}

Number of relevés: 28

Type relevé: 2130 (holotype), sampled on 9 February 2005 at $23^{\circ} 05^{\prime} 29^{\prime \prime} \mathrm{S}, 16^{\circ} 39^{\prime} 29^{\prime \prime} \mathrm{E}$

Number of species observed: 156

Estimated number of species: 209

Average species density per $1000 \mathrm{~m}^{2}: 51$
Diagnostic species: Panicum arbusculum, Hibiscus discophorus, Ipomoea obscura var. obscura, Aristida meridionalis, Talinum arnotii, Blepharis mitrata, Brachiaria nigropedata, Catophractes alexandri

Constant species: Senegalia mellifera subsp. detinens, Leucosphaera bainesii, Kyphocarpa angustifolia, Eragrostis nindensis, Phaeoptilum spinosum, Microchloa caffra, Chascanum pinnatifidum, Stipagrostis uniplumis var. uniplumis, Fingerhuthia africana, Grewia flava, Ptycholobium biflorum, Melinis repens subsp. grandiflora, Eriocephalus luederitzianus, Schmidtia pappophoroides, Melhania virescens, Limeum myosotis, Aristida adscensionis, Aptosimum albomarginatum, Aizoon schellenbergii, Otoptera burchellii, Ocimum americanum var. americanum, Monelytrum luederitzianum, Hermannia modesta, Enneapogon cenchroides, Cenchrus ciliaris, Aptosimum spinescens, Lycium eenii, Lycium bosciifolium, Hirpicium gazanioides, Barleria rigida, Asparagus exuvialis, Searsia marlothii, Raphionacme velutina, Phyllanthus maderaspatensis, Antizoma angustifolia, Kyllinga alba, Dicoma capensis, Anthephora pubescens

These tall, moderately closed shrublands are dominated by Senegalia mellifera subsp. detinens, Catophractes alexandri, Rhigozum trichotomum and Monechma genistifolium. The grass layer contains Panicum arbusculum, Stipagrostis uniplumis var. uniplumis, Melinis repens subsp. grandiflora, Eragrostis nindensis and Aristida congesta subsp. congesta (Figures 10D and 11D). The presence of Rhigozum trichotomum and Panicum arbusculum within this southern Khomas Hochland is indicative of the transitional nature of these shrublands to the Dwarf Shrub Savanna sensu Giess (1998) or Nama Karoo. This association occurs on the rolling to moderately steep hilly landscape of the southern Khomas Hochland, and is especially well-represented along the C26. The underlying geology is formed by the mixtites of the Chuos Formation. Stone cover is about $40 \%$, mainly small and medium-sized stones. The altitude ranges between 1650 and $1850 \mathrm{~m}$ asl, whilst the MAP ranges between 200 and $300 \mathrm{~mm}$.

\subsection{Elephantorrhizo suffruticosae- Euphorbietum guerichianae ass. nov.}

\section{Synopsis:}

Number of relevés: 24

Type relevé: 2019 (holotype), sampled on 20 February 2004 at $23^{\circ} 15^{\prime} 04^{\prime \prime} \mathrm{S}, 16^{\circ} 19^{\prime} 02^{\prime \prime} \mathrm{E}$

Number of species observed: 114

Estimated number of species: 172

Average species density per $1000 \mathrm{~m}^{2}: 35$

Diagnostic species: Euphorbia guerichiana, Heliotropium nelsonii, Elephantorrhiza suffruticosa, Cheilanthes marlothii, Commiphora glandulosa, Setaria 
appendiculata, Helichrysum tomentosulum, Triraphis ramosissima, Blepharis obmitrata, Tephrosia dregeana var. dregeana, Emilia marlothiana, Anthephora pubescens, Cyphostemma currorii, Ozoroa crassinervia, Manuleopsis dinteri, Montinia caryophyllacea, Tribulus zeyheri, Boscia albitrunca

Constant species: Stipagrostis uniplumis var. uniplumis, Otoptera burchellii, Eragrostis nindensis, Talinum caffrum, Searsia marlothii, Fingerhuthia africana, Phaeoptilum spinosum, Hermannia modesta, Monechma spartioides, Cenchrus ciliaris, Vachellia reficiens, Melinis repens subsp. grandiflora, Combretum apiculatum subsp. apiculatum, Chascanum pinnatifidum, Aristida adscensionis

These short, moderately closed bushlands occur in the upper reaches of the escarpment zone, between 1450 and $1780 \mathrm{~m}$ asl. The slopes are generally very steep (Figures $10 \mathrm{E}$ and 11E). This association is dominated by Vachellia reficiens, Elephantorrhiza suffruticosa, Senegalia erubescens, as well as the grasses Stipagrostis uniplumis var. uniplumis, Eragrostis nindensis and Setaria appendiculata. The latter again is an indication of a transition to mountainous habitats in the Nama Karoo biome. Geology is varied, however mostly mica schists of the Kuiseb Formation and quarzites of the Auas formation (Geological Survey 1980; South African Committee for Stratigraphy 1980). Especially rock cover is high, with up to $80 \%$ of the surface covered by large stones and/ or rocks. MAP ranges between 200 and $300 \mathrm{~mm}$, not taking any orographic effects into account.

\subsection{Dichrostachyo cinereae-Senegalietum erubescentis ass. nov.}

\section{Synopsis:}

Number of relevés: 91

Type relevé: 9494 (holotype), sampled on 16 March 2009 at $22^{\circ} 18^{\prime} 10^{\prime \prime} \mathrm{S}, 16^{\circ} 27^{\prime} 40^{\prime \prime} \mathrm{E}$
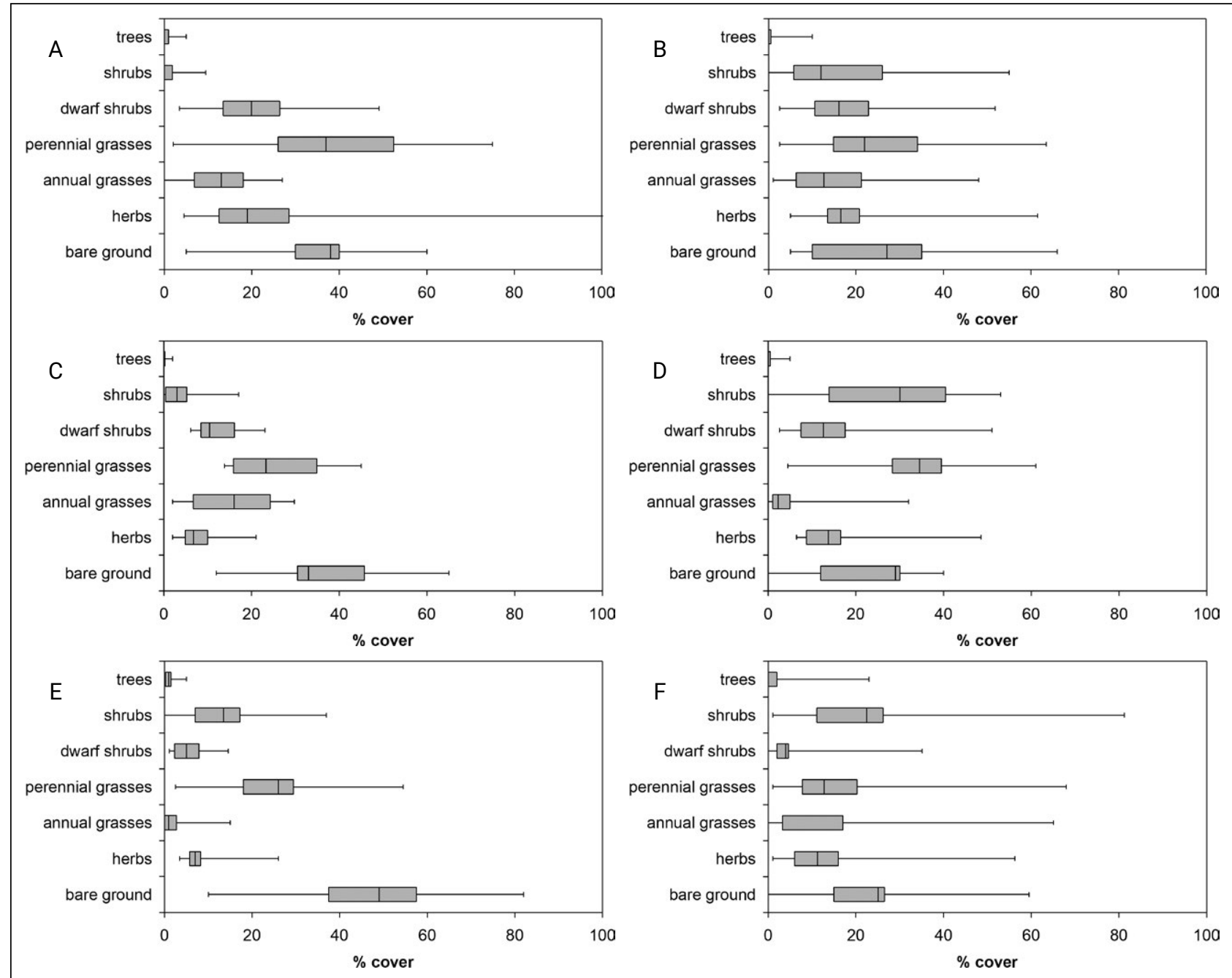

Figure 10. Box-and-Whisker plots of the typical structure of the associations of the Khomas Hochland Proper, based on the relevé data. A, Pseudogaltonio clavatae-Eriocephaloetum luederitziana; B, Panico lanipedis-Pentzietum incanae; C, Aptosimo spinescentis-Galenietum africanae; D, Panico arbusculi-Senegalietum detinentis; E, Elephantorrhizo suffruticosae-Euphorbietum guerichianae; F, Dichrostachyo cinereae-Senegalietum erubescentis. 
Number of species observed: 270

Estimated number of species: 383

Average species density per $1000 \mathrm{~m}^{2}: 39$

Diagnostic species: Senegalia erubescens, Dichrostachys cinerea, Grewia flavescens, Combretum apiculatum subsp. apiculatum, Hibiscus elliottiae

Constant species: Stipagrostis uniplumis var. uniplumis, Enneapogon cenchroides, Senegalia mellifera subsp. detinens, Melinis repens subsp. grandiflora, Eragrostis nindensis, Cenchrus ciliaris, Catophractes alexandri, Vachellia reficiens, Pogonarthria fleckii, Kyphocarpa angustifolia, Triraphis ramosissima, Aristida effusa, Anthephora pubescens, Pupalia lappacea, Grewia flava, Boscia albitrunca, Ptycholobium biflorum

These high, moderately closed shrublands are dominated by the shrub species Senegalia erubescens, Vachellia reficiens, Senegalia mellifera subsp. detinens, Melinis repens subsp. grandiflora and Dichrostachys cinerea. The grass layer is dominated by Enneapogon cenchroides, Eragrostis nindensis, Stipagrostis uniplumis var. uniplumis and Schmidtia kalahariensis (Figures 10F and 11F). This association occurs in the rolling to moderately steep lowlands in the Windhoek valley, as well as Swakop valley around Okahandja. Some patches of this have also been observed in the upper Kuiseb valley. The altitude ranges between 1300 and $1800 \mathrm{~m}$ asl. Geology is varied, mainly mica schists from the Kuiseb formation, but also various intrusive granitic formations in the Swakop valley around Okahandja. Surface stone cover reaches between 40 and $80 \%$, mainly small and medium stones. MAP ranges between 200 and $350 \mathrm{~mm}$.

\subsection{Schmidtio kalahariensis- vachellietum eriolobae ass. nov.}

\section{Synopsis:}

Number of relevés: 26
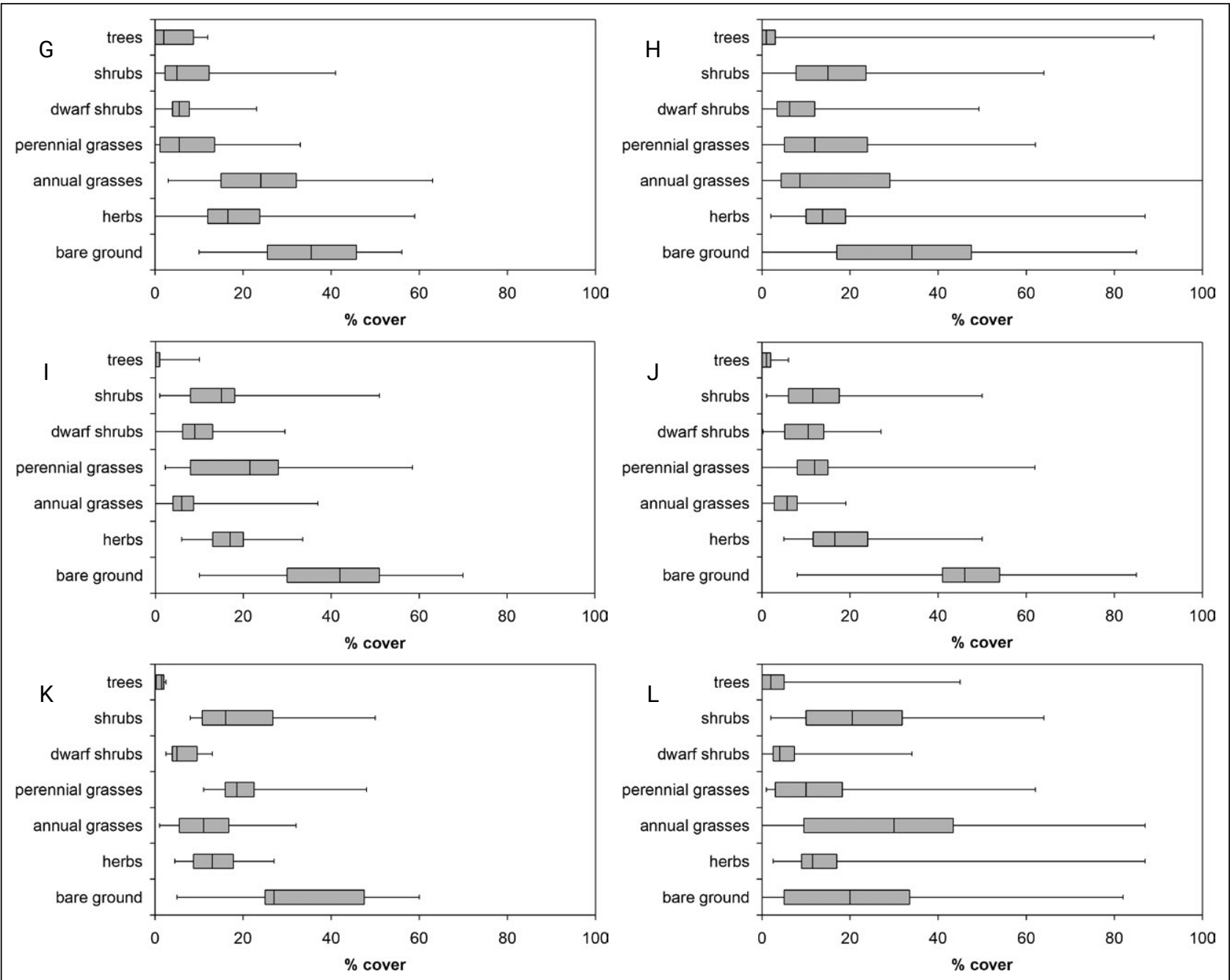

Figure 10 (continued). Box-and-Whisker plots of the typical structure of the associations of the Khomas Hochland Proper, based on the relevé data. G, Schmidtio kalahariensis-Vachellietum eriolobae; H, Stipagrostis uniplumis-Senegalia detinens association; I, Stipagrostis uniplumis-Senegalia detinens typical sub-association; J, Stipagrostis uniplumis-Senegalia detinens tarchonanthus camphoratus sub-association; K, Stipagrostis uniplumis-Senegalia detinens vachellia tortilis sub-association; L, Stipagrostis uniplumis-Senegalia detinens vachellia reficiens sub-association. 
Type relevé: 1082 (holotype), sampled on 22 April 2002 at $22^{\circ} 52^{\prime} 49^{\prime \prime} \mathrm{S}, 17^{\circ} 06^{\prime} 13^{\prime \prime} \mathrm{E}$

Number of species observed: 103

Estimated number of species: 161

Average species density per $1000 \mathrm{~m}^{2}: 27$

Diagnostic species: Schmidtia kalahariensis, Hermbstaedtia fleckii, Eragrostis cylindriflora

Constant species: Phaeoptilum spinosum, Vachellia erioloba, Stipagrostis uniplumis var. uniplumis, Enneapogon cenchroides, Acrotome fleckii, Senegalia mellifera subsp. detinens, Pollichia campestris, Eragrostis porosa, Gisekia africana, Geigeria pectidea

These tall, semi-open bushlands are dominated by Vachellia erioloba trees, interspersed by shrubs of Senegalia mellifera subsp. detinens and Lycium bosciifolium. The grass layer is dominated by Schmidtia kalahariensis and Stipagrostis uniplumis var. uniplumis. Conspicuous are the suffrutex Elephantorrhiza elephantina and the forb Geigeria pectidea (Figures 10G and 11G). This association occurs on the alluvial plains around Aris and at Omeya south of Windhoek but has also been observed in the Brakwater/Döbra area in the valley north of Windhoek. The slopes are flat to gently undulating, with hardly any stone cover (mostly gravel and small stones, less than 2\%). The altitude ranges between 1600 and $1770 \mathrm{~m}$ asl, with MAP of between 300 and $350 \mathrm{~mm}$.

\subsection{Stipagrostis uniplumis-Senegalia detinens association}

\section{Synopsis:}

Number of relevés: 162

Number of species observed: 317

Estimated number of species: 473

Average species density per $1000 \mathrm{~m}^{2}: 41$

\section{Diagnostic species: none}

Constant species: Senegalia mellifera subsp. detinens, Stipagrostis uniplumis var. uniplumis, Enneapogon cenchroides, Kyphocarpa angustifolia, Cenchrus ciliaris, Ocimum americanum var. americanum, Melinis repens subsp. grandiflora, Eragrostis nindensis, Catophractes alexandri, Eragrostis porosa, Grewia flava, Boscia albitrunca, Aristida adscensionis, Ziziphus mucronata, Lycium bosciifolium, Otoptera burchellii, Phaeoptilum spinosum, Pogonarthria fleckii, Ptycholobium biflorum

These tall, semi-open shrublands are dominated by Senegalia mellifera subsp. detinens, Catophractes alexandri, Vachellia reficiens and Phaeoptilum spinosum (Figure $10 \mathrm{H})$. This association is often associated with degradation within various units in the Khomas Hochland, but also the regular Thornbush savanna elements to the east and north of the Khomas Hochland. Although four distinct forms have been recognised (and described as sub-associations below), there is still sufficient uncertainty regarding the classification not to allow a formal description of these communities yet.

\subsubsection{Stipagrostis uniplumis-Senegalia detinens typical sub-association}

\section{Synopsis:}

Number of relevés: 46

Number of species observed: 193

Estimated number of species: 286

Average species density per $1000 \mathrm{~m}^{2}: 42$

Diagnostic species: none

Constant species: Stipagrostis uniplumis var. uniplumis, Phaeoptilum spinosum, Senegalia mellifera subsp. detinens, Ocimum americanum var. americanum, Eragrostis nindensis, Kyphocarpa angustifolia, Grewia flava, Enneapogon cenchroides, Schmidtia pappophoroides, Talinum caffrum, Hirpicium gazanioides, Otoptera burchellii, Catophractes alexandri, Aristida congesta subsp. congesta, Ziziphus mucronata, Hermannia modesta, Vachellia hebeclada subsp. hebeclada, Kyllinga alba, Gisekia africana, Aristida adscensionis, Indigofera vicioides, Eragrostis porosa, Dicoma capensis, Cenchrus ciliaris, Boscia albitrunca, Lycium eenii, Chascanum pinnatifidum

These tall, semi-open shrublands are the typical form of the Stipagrostis uniplumis-Senegalia detinens association (Figures $10 \mathrm{I}$ and $11 \mathrm{H}$ ). Strohbach (2017) referred to this as the 'Pupalia lappacea-Acacia mellifera bush encroached lowlands', indicating that this association is often a degradation state of other associations. As Pupalia lappacea however was not found to be a diagnostic nor constant species, the proposed name was rejected. This sub-association is found as patches in various components and associations within the Khomas Hochland. Especially the Brachiario nigropedatae-Senegalietum hereroensis, the Panico arbusculi-Senegalietum detinentis and the Panico lanipedis-Pentzietum incanae seem prone to degradation to this state.

The Stipagrostis uniplumis-Senegalia detinens typical sub-association occurs on undulating to rolling slopes, often with up to $40 \%$ gravel and small stone cover, at altitudinal ranges between 1650 and $1800 \mathrm{~m}$ asl.

\subsubsection{Stipagrostis uniplumis-Senegalia detinens tarchonanthus camphoratus sub-association}

\section{Synopsis:}

Number of relevés: 35

Number of species observed: 194 
Estimated number of species: 300

Average species density per $1000 \mathrm{~m}^{2}: 42$

Diagnostic species: Tarchonanthus camphoratus

Constant species: Senegalia mellifera subsp. detinens, Stipagrostis uniplumis var. uniplumis, Enneapogon cenchroides, Ocimum americanum var. americanum, Cenchrus ciliaris, Boscia albitrunca, Phaeoptilum spinosum, Lycium eenii, Ziziphus mucronata, Schmidtia pappophoroides, Otoptera burchellii, Grewia flava, Eragrostis porosa, Eragrostis nindensis, Achyranthes aspera var. sicula, Searsia marlothii, Pavonia burchellii, Catophractes alexandri, Kyphocarpa angustifolia, Vachellia erioloba, Pogonarthria fleckii, Monechma spartioides, Melinis repens subsp. grandiflora, Hermannia modesta, Talinum caffrum, Leucosphaera bainesii, Leucas pechuelii, Gisekia africana, Eragrostis echinochloidea, Ehretia rigida

These high, semi-open shrublands are also dominated by Senegalia mellifera subsp. detinens and Catophractes alexandri (Figures 10J and 11I). The occurrence of Tarchonanthus camphoratus indicates slightly moister conditions, reflected in deeper, sandier soils, but also higher rainfall regimes (between 350 and $400 \mathrm{~mm}$ MAP). This sub-association is found in the eastern parts of the study area, linking into the thornbush savanna types to the east of Windhoek. The altitude ranges between 1550 and $1830 \mathrm{~m}$ asl, with rolling to moderately steep slopes. The subsurface geology are granites and gneiss from the Hohewarte complex and Gamsberg Suite. Stone cover is low $(<15 \%)$, mostly gravel and small stones.

\subsubsection{Stipagrostis uniplumis- Senegalia detinens vachellia tortilis sub-association}

\section{Synopsis:}

Number of relevés: 12

Number of species observed: 156

Estimated number of species: 267

Average species density per $1000 \mathrm{~m}^{2}: 39$

Diagnostic species: none

Constant species: Melinis repens subsp. grandiflora, Enneapogon cenchroides, Cenchrus ciliaris, Pogonarthria fleckii, Eragrostis porosa, Ziziphus mucronata, Stipagrostis uniplumis var. uniplumis, Eragrostis nindensis, Senegalia mellifera subsp. detinens, Searsia marlothii, Phaeoptilum spinosum, Aristida adscensionis, Anthephora pubescens, Triraphis ramosissima, Schmidtia pappophoroides, Eragrostis rigidior, Aristida congesta subsp. congesta, Ocimum americanum var. americanum, Nidorella resedifolia, Monechma divaricatum, Lycium bosciifolium, Eragrostis echinochloidea
These short, semi-open bushlands are dominated by Vachellia reficiens, Senegalia mellifera subsp. detinens and Vachellia tortilis (Figure 10K). It has a limited occurrence in patches in the Khomas Hochland and has mainly been observed west of Windhoek in the Daan Viljoen Game Reserve. This sub-association occurs on moderately steep to steep slopes at altitudinal ranges between 1500 and $1800 \mathrm{~m}$ asl. Stone cover is fairly high, above $40 \%$, mostly small and medium stones. Larger stones, and occasional rock outcrops, are also present. The subsurface geology is also mica-schists of the Kuiseb Formation.

\subsubsection{Stipagrostis uniplumis- Senegalia detinens vachellia reficiens sub-association}

\section{Synopsis:}

Number of relevés: 69

Type relevé: 9504 (holotype), sampled on 16 March 2009 at $21^{\circ} 55^{\prime} 51^{\prime \prime} \mathrm{S}, 16^{\circ} 34^{\prime} 36^{\prime \prime} \mathrm{E}$

Number of species observed: 219

Estimated number of species: 341

Average species density per $1000 \mathrm{~m}^{2}: 39$

Diagnostic species: none

Constant species: Senegalia mellifera subsp. detinens, Stipagrostis uniplumis var. uniplumis, Vachellia reficiens, Enneapogon cenchroides, Lycium bosciifolium, Melinis repens subsp. grandiflora, Albizia anthelmintica, Kyphocarpa angustifolia, Catophractes alexandri, Aristida adscensionis, Cenchrus ciliaris, Ptycholobium biflorum, Eragrostis porosa, Boscia albitrunca, Aristida effusa, Pupalia lappacea, Schmidtia kalahariensis, Leucosphaera bainesii, Pogonarthria fleckii, Commelina benghalensis, Ocimum americanum var. americanum, Achyranthes aspera var. sicula

These short, moderately closed bushlands are dominated by Senegalia mellifera subsp. detinens, Vachellia reficiens and Catophractes alexandri (Figures 10L and 11J). The grass layer is dominated by Schmidtia kalahariensis, Enneapogon cenchroides, Stipagrostis uniplumis var. uniplumis and Aristida adscensionis. This sub-association occurs in mosaic with the Dichrostachyo cinereaeSenegalietum erubescentis in the Windhoek valley and the Swakop Valley to the west of Okahandja. The relationship between these two syntaxa is not clear.

The Stipagrostis uniplumis-Senegalia detinens vachellia reficiens sub-association_occurs at an altitudinal range of between 1500 and $1800 \mathrm{~m}$ asl, on rolling to moderately steep slopes. Geology is varied, mostly mica schists and granites. Stone cover is mostly by gravel, small and medium sized stones, less than $40 \%$. MAP ranges between 200 and $400 \mathrm{~mm}$. 

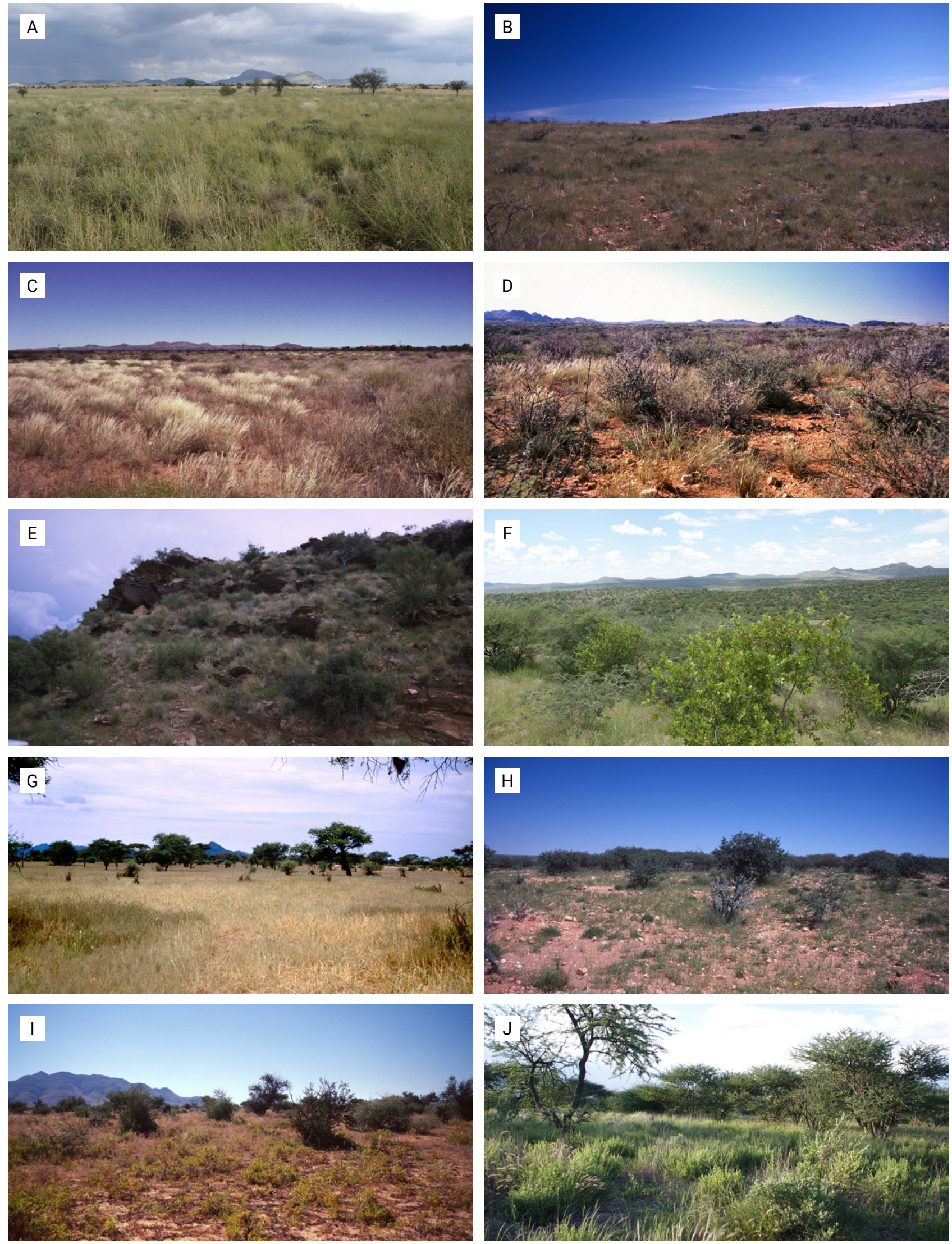

Figure 11. Typical views of the associations of the Khomas Hochland Proper. A, Pseudogaltonio clavatae-Eriocephaloetum luederitziana; B, Panico lanipedis-Pentzietum incanae, relevé 1020; C, Aptosimo spinescentis-Galenietum africanae, relevé 2155; D, Panico arbusculi-Senegalietum detinentis, relevé 2153; E, Elephantorrhizo suffruticosae-Euphorbietum guerichianae, relevé 2017; F, Dichrostachyo cinereae-Senegalietum erubescentis, relevé 9494; G, Schmidtio kalahariensis-Vachellietum eriolobae, relevé 1082; H, Stipagrostis uniplumis-Senegalia detinens typical sub-association, relevé 982; I, Stipagrostis uniplumis-Senegalia detinens tarchonanthus camphoratus sub-association, relevé 1146; J, Stipagrostis uniplumis-Senegalia detinens vachellia reficiens sub-association, relevé 9504. 


\section{Higher syntaxonomy}

The classification of the synoptic relevés of 30 associations yielded a classification with crispness peaks at 4 , 8 , and 14/15 divisions. Accordingly, a classification with 15 clusters was accepted and interpreted. The 15 clusters were interpreted as alliances, whilst these alliances were grouped into orders between level 4 and level 8 divisions (Figure 12). An overview of associations, associated with their relevant alliances, orders and broad habitats are given in Table 3.

The Senegalio hereroensis-Tarchonanthoetalia camphorati is typified by the Senegalio hereroensis-Tarchonanthion camphorati. This order represents the high mountains of central Namibia. Based on the present data, it can be subdivided into two alliances, being the Senegalio hereroensis-Tarchonanthion camphorati, representing the Auas Mountains, as well as the Digitario erianthae-Euryion walterorum, representing the Gamsberg Mountain. The Senegalio hereroensis-Tarchonanthion camphorati is typified by the Senegalio hereroensis-Tarchonanthoetum camphorati and contains also the two other associations occurring on the Auas Mountains. The Digitario erianthae-Euryion walterorum is typified by the Digitario erianthae-Euryopietum walterorum and contains only this association.

The Cynodo dactylonis-Eragrostioetalia rotiferi is recognised as a provisional order representing the riverine habitats. According to the present classification, it breaks up into five alliances, each representing a single association. Due to this, and as other, similar habitats exist in central and southern Namibia, this provisional order is not yet formally described pending a thorough revision.

The Brachiario nigropedatae-Senegalietalia hereroensis is typified by the Brachiario nigropedatae-Senegalion hereroensis, which is also the only alliance to this order. This order represents the vegetation of the central Khomas Hochland. The Brachiario nigropedatae-Senegalion hereroensis in turn is typified by the Brachiario nigropedatae-Senegalietum hereroensis. In addition to the typical association, three other associations have been grouped into this alliance. Two of these represent rocky habitats typical for the central Khomas Hochland, the third represents smaller rivers within the Khomas Hochland.

The sandy and/or specialised habitats in desert environment form a cluster of associations, each being represented by an own alliance, and possibly (depending on interpretation), even own orders. One of these associations, the Salvadoro persicae- Eucleetum pseudebeno, could possibly also be grouped with the Cynodo dactylonis- Eragrostioetalia rotiferi due to its habitat. This is speculative, and subject to review in future. Because of this, no formal higher syntaxonomic groupings are described here.

The Eragrostio nindensis-Vachellietalia reficientis is typified by the Eragrostio nindensis-Vachellion reficientis. This order represents the Pre-Namib as well as the escarpment zone. The classification does not present any evidence of this order to be split into two alliances, yet, based on the habitat and vegetation of the associations in this order, a split was made between the name-giving alliance and the Enneapogono desvauxii-Eragrostion nindensis. The Eragrostio nindensis-Vachellion reficientis is typified by the Eragrostio nindensis-Vachellietum reficientis and includes two other association within the escarpment zone. The Enneapogono desvauxii-Eragrostion nindensis is typified by the Enneapogono desvauxiiEragrostietum nindensis and includes the closely related Enneapogono desvauxii-Adenoloboetum pechuelii, as part of the Pro-Namib landscape.

The Panico arbusculi-Senegalietalia detinentis is typified by the Panico arbusculi-Senegalion detinentis. It includes

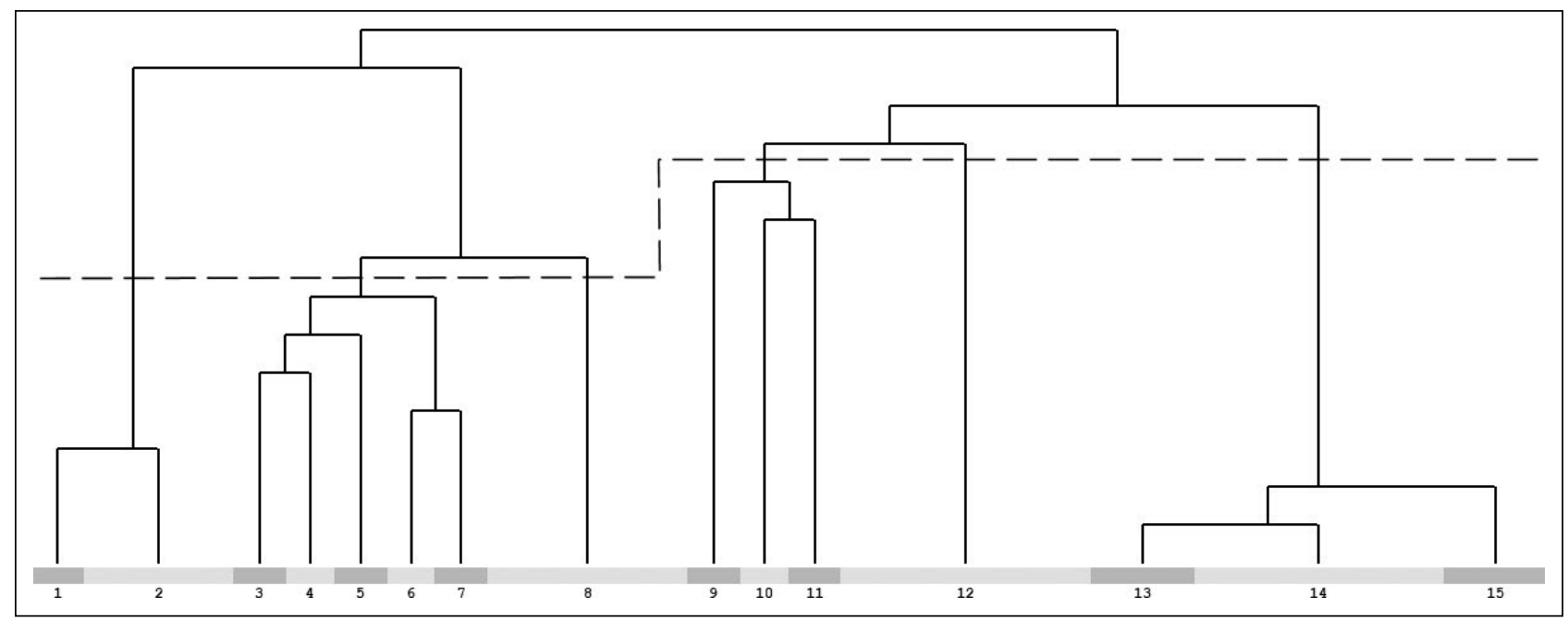

Figure 12. Dendrogram of the classification of synoptic relevés representing various associations. Groupings above the stippled line were interpreted as orders, whilst the final groupings were interpreted as alliances. 
Table 3. Overview of the higher syntaxonomy of associations described in this study

\begin{tabular}{|c|c|c|c|}
\hline & Association & Alliance & Order \\
\hline 2.1 & $\begin{array}{l}\text { Digitario erianthae- } \\
\text { Euryopietum walterorum }\end{array}$ & $\begin{array}{l}\text { Digitario erianthae- } \\
\text { Euryion walterorum }\end{array}$ & $\begin{array}{l}\text { Senegalio hereroensis- } \\
\text { Tarchonanthoetalia camphorati }\end{array}$ \\
\hline 2.3 & $\begin{array}{l}\text { Eriocephalo dinteri- } \\
\text { Danthoniopietum ramosae }\end{array}$ & \multirow[t]{3}{*}{$\begin{array}{l}\text { Senegalio hereroensis- } \\
\text { Tarchonanthion camphorati }\end{array}$} & \multirow[t]{3}{*}{ High Mountains } \\
\hline 2.5 & $\begin{array}{l}\text { Senegalio hereroensis- } \\
\text { Tarchonanthoetum camphorati }\end{array}$ & & \\
\hline 2.4 & $\begin{array}{l}\text { Danthoniopio ramosae- } \\
\text { Oleoetum africanae }\end{array}$ & & \\
\hline 3.1 & $\begin{array}{l}\text { Eragrostio rotiferi- } \\
\text { Oleoetum africanae }\end{array}$ & & \multirow{5}{*}{$\begin{array}{l}\text { Cynodo dactylonis- } \\
\text { Eragrostioetalia rotiferi } \\
\text { Rivers }\end{array}$} \\
\hline 3.7 & Setario finitae-Vachellietum eriolobae & & \\
\hline 3.3 & Stipagrostioetum namaquensis & & \\
\hline 3.2 & $\begin{array}{l}\text { Cynodo dactylonis- } \\
\text { Eragrostioetum rotiferi }\end{array}$ & & \\
\hline 3.4 & $\begin{array}{l}\text { Themedio triandrae- } \\
\text { Chloroetum virgatae }\end{array}$ & & \\
\hline 2.2 & $\begin{array}{l}\text { Pennisetum foermerianum- } \\
\text { Ficus ilicina association }\end{array}$ & \multirow{4}{*}{$\begin{array}{l}\text { Brachiario nigropedatae- } \\
\text { Senegalion hereroensis } \\
\text { Khomas Hochland proper }\end{array}$} & \multirow{4}{*}{$\begin{array}{l}\text { Brachiario nigropedatae- } \\
\text { Senegalietalia hereroensis } \\
\text { Khomas Hochland proper }\end{array}$} \\
\hline 2.6 & $\begin{array}{l}\text { Triraphio ramosissimae- } \\
\text { Manuleopsietum dinteri }\end{array}$ & & \\
\hline 3.5 & $\begin{array}{l}\text { Chloro virgatae- } \\
\text { Vachellietum karroo }\end{array}$ & & \\
\hline 2.8 & $\begin{array}{l}\text { Brachiario nigropedatae- } \\
\text { Senegalietum hereroensis }\end{array}$ & & \\
\hline 1.4 & $\begin{array}{l}\text { Tribulocarpo dimorphantho- } \\
\text { Vachellietum eriolobae }\end{array}$ & & \multirow{3}{*}{$\begin{array}{l}\text { Sandy and/or specialised habitats in } \\
\text { desert environment }\end{array}$} \\
\hline 1.3 & $\begin{array}{l}\text { Crotalario podocarpae- } \\
\text { Stipagrostioetum obtusae }\end{array}$ & & \\
\hline 3.6 & $\begin{array}{l}\text { Salvadoro persicae- } \\
\text { Eucleetum pseudebeno }\end{array}$ & & \\
\hline 1.1 & $\begin{array}{l}\text { Enneapogono desvauxii- } \\
\text { Adenoloboetum pechuelii }\end{array}$ & \multirow[t]{2}{*}{$\begin{array}{l}\text { Enneapogono desvauxii- } \\
\text { Eragrostion nindensis }\end{array}$} & \multirow{5}{*}{$\begin{array}{l}\text { Eragrostio nindensis- } \\
\text { Vachellietalia reficientis } \\
\text { Desert \& escarpment }\end{array}$} \\
\hline 1.2 & $\begin{array}{l}\text { Enneapogono desvauxii- } \\
\text { Eragrostietum nindensis }\end{array}$ & & \\
\hline 1.6 & $\begin{array}{l}\text { Myrothamno flabellifolii- } \\
\text { Commiphoroetum dinteri }\end{array}$ & \multirow[t]{3}{*}{$\begin{array}{l}\text { Eragrostio nindensis- } \\
\text { Vachellion reficientis }\end{array}$} & \\
\hline 1.5 & $\begin{array}{l}\text { Geigerio acaulis- } \\
\text { Commiphoroetum glaucescentis }\end{array}$ & & \\
\hline 1.7 & $\begin{array}{l}\text { Eragrostio nindensis- } \\
\text { Vachellietum reficientis }\end{array}$ & & \\
\hline 2.7 & $\begin{array}{l}\text { Ornithoglosso calcicolae- } \\
\text { Fingerhuthioetum africanae }\end{array}$ & \multirow{2}{*}{$\begin{array}{l}\text { Elephantorrhizo suffruticosa- } \\
\text { Euphorbion guerichianae } \\
\text { Mountainous fringes of the Khomas } \\
\text { Hochland }\end{array}$} & $\begin{array}{l}\text { Panico arbusculi- } \\
\text { Senegalietalia detinentis }\end{array}$ \\
\hline 4.5 & $\begin{array}{l}\text { Elephantorrhizo suffruticosae- } \\
\text { Euphorbietum guerichianae }\end{array}$ & & \multirow[t]{2}{*}{$\begin{array}{l}\text { Lowlands along the Khomas } \\
\text { Hochland fringes }\end{array}$} \\
\hline 4.7 & $\begin{array}{l}\text { Schmidtio kalahariensis- } \\
\text { Vachellietum eriolobae }\end{array}$ & $\begin{array}{l}\text { Panico arbusculi- } \\
\text { Senegalion detinentis }\end{array}$ & \\
\hline
\end{tabular}


Table 3. Overview of the higher syntaxonomy of associations described in this study (continued)

\begin{tabular}{|c|c|c|c|}
\hline & Association & Alliance & Order \\
\hline 4.1 & $\begin{array}{l}\text { Pseudogaltonio clavatae- } \\
\text { Eriocephaloetum luederitziana }\end{array}$ & \multirow{4}{*}{$\begin{array}{l}\text { Southern fringe communities - } \\
\text { ecotone to Nama Karoo }\end{array}$} & \\
\hline 4.3 & $\begin{array}{l}\text { Aptosimo spinescentis- } \\
\text { Galenietum africanae }\end{array}$ & & \\
\hline 4.4 & $\begin{array}{l}\text { Panico arbusculi- } \\
\text { Senegalietum detinentis }\end{array}$ & & \\
\hline 4.2 & $\begin{array}{l}\text { Panico lanipedis- } \\
\text { Pentzietum incanae }\end{array}$ & & \\
\hline 4.6 & $\begin{array}{l}\text { Dichrostachyo cinereae- } \\
\text { Senegalietum erubescentis }\end{array}$ & \multirow{2}{*}{$\begin{array}{l}\text { Dichrostachyo cinereae- } \\
\text { Senegalion erubescentis } \\
\text { Northern and eastern fringe lowlands }\end{array}$} & \\
\hline 4.8 & $\begin{array}{l}\text { Stipagrostis uniplumis- } \\
\text { Senegalia detinens association }\end{array}$ & & \\
\hline
\end{tabular}

two other alliances, being the Elephantorrhizo suffruticosae-Euphorbion guerichianae and the Dichrostachyo cinereae-Senegalion erubescentis. This order represents the fringes to the Khomas Hochland to the south, east, north and, in the form of the upper escarpment, west. The Panico arbusculi-Senegalion detinentis in turn is typified by the Panico arbusculi-Senegalietum detinentis, and, together with four other associations, forms the transition to the Nama Karoo biome to the south. The Schmidtio kalahariensis-Vachellietum eriolobae is closely related to the vegetation of the southern Kalahari (Strohbach et al. 2019).

The Elephantorrhizo suffruticosae-Euphorbion guerichianae is typified Elephantorrhizo suffruticosae-Euphorbietum guerichianae and represents the mountainous habitats along the southern and western fringes of the Khomas Hochland. It contains one other association, the Ornithoglosso calcicolae-Fingerhuthioetum africanae of the Oamites mountain.

The Dichrostachyo cinereae-Senegalion erubescentis is typified by the Dichrostachyo cinereae-Senegalietum erubescentis and includes the as yet not formally described Stipagrostis uniplumis-Senegalia detinens association. This alliance represents the northern and eastern lowlands associated with the Khomas Hochland.

\section{Discussion and conclusion}

The higher syntaxonomy confirmed several preliminary observations. The initial classification into Pre-Namib and Escarpment, Khomas Hochland proper, Riverine habitats as well as surrounding lowlands are largely reflected in the orders Cynodo dactylonis-Eragrostioetalia rotiferi, the Brachiario nigropedatae-Senegalietalia hereroensis, the Eragrostio nindensis-Vachellietalia reficientis and the Panico arbusculi-Senegalietalia detinentis. This is also in line with the groupings proposed by Giess (1998), i.e. the Central Namib, the Desert transition and escarpment Zone as well as the Highland savanna.

A notable exception is the Senegalio hereroensis-Tarchonanthoetalia camphorati (high mountains), which is highlighted as a grouping on its own. This also confirms the findings of Strohbach (2017), who has highlighted the high Auas Mountain vegetation as a separate grouping. The Senegalio hereroensis-Tarchonanthoetalia camphorati has close affinities to the grassland biome of South Africa, with its dominant cover of grasses, in particular Digitaria eriantha (Mucina \& Rutherford 2006). Prominent representatives of the Asteraceae in this order, amongst others Eriocephalus spp., Stoebe plumosa and Euryops walterorum, also have close relatives in the grasslands and adjacent Karoo vegetation in South Africa (cf. Nordenstam 1966; Müller et al. 2001; Njenga 2005), indicating a biogeographic relationship to these biomes, rather than the surrounding savanna biome.

The other notable exception is the formation of a cluster of specialised habitats within the desert biome environment. Although the Salvadoro persicae-Eucleetum pseudebeno has distinct affinities to the inland rivers, it still groups into the desert environment rather than the inland savanna environment. Of the other two associations in this cluster, the Crotalario podocarpae-Stipagrostioetum obtusae has affinities to the arid grasslands of the Nama Karoo biome (Mucina \& Rutherford 2006), whilst the Tribulocarpo dimorphantho-Vachellietum eriolobae has affinities to the Kalahari duneveld sensu Mucina and Rutherford (2006) or southern Kalahari sensu Giess (1998).

The vegetation classification and description presented in this paper represents a broad overview, as dictated by the 'reconnaissance level' scale. Intensified sampling in several specialist habitats, e.g. the riverine habitats, 
the high mountains (in particular the Hakos mountains, as well as ranges like the Bismark Mountains east of the Auas and various ranges of the Kamtsas and Sinclair formations south of Windhoek) and the Matchless Member dissecting the central Khomas Hochland, will likely yield further associations. The higher syntaxonomy will likely also be clarified and strengthened once more such studies are available and included in the analysis.

\section{Acknowledgements}

I would like to acknowledge the permission granted by many farmers to work on their properties, as well as the hospitality afforded by these. Tuhafeni Sheuyange, Zuna September and Salomé Kruger assisted with the data collection, whilst the data contributed by Coleen Mannheimer, Martin Wittneben and Dr Antje Burke is gratefully acknowledged. The staff of the National Herbarium of Namibia (WIND) helped with the identification of numerous specimens. The project was financially supported by the recurrent budget of the Ministry of Agriculture, Water and Forestry (Vote 2004) as well as the BIOTA southern Africa Project, in turn funded by the German Federal Ministry of Education and Research under their promotion number 01LC0624.

\section{Competing interests:}

The author declares that he has no financial or personal relationship that may have inappropriately influenced him in writing this article.

\section{References}

BIOTA AFRICA, 2009, 'BIOdiversity Monitoring Transect Analysis in Africa' [online], BIOdiversity Monitoring Transect Analysis in Africa, Available from: https://www.biota-africa.org/ [Accessed 31 May 2020].

Botha, L., 1998, 'History of drought in Namibia', Agricola, 10: 5-12.

Botta-Dukát, Z., Chytrý, M., Hájková, P. \& Havlová, M., 2005, 'Vegetation of lowland wet meadows along a climatic continentality gradient in Central Europe', Preslia, 77: 89-111.

Brown, L.R., du Preez, P.J., Bezuidenhout, H., Bredenkamp, G.J., Mostert, T.H., Collins, N.B. \& Park, K., 2013, 'Guidelines for phytosociological classifications and descriptions of vegetation in southern Africa', Koedoe - African Protected Area Conservation and Science, 55: 1103, 10.4102/ koedoe.v55i1.1103.

Bruelheide, H., 1997, 'Using formal logic to classify vegetation', Folia Geobotanica Phytotaxonomia, 32(1): 41-46, 10.1007/BF02803883.

Bruelheide, H. \& Flintrop, T., 1994, 'Arranging phytosociological tables by species-relevé groups', Journal of Vegetation Science, 5(3): 311-316, 10.2307/3235854.

Burke, A. \& Strohbach, B.J., 2000, 'Vegetation studies in Namibia', Dinteria, 26: 1-24.

Burke, A. \& Wittneben, M., 2007, 'A preliminary account of the vegetation of the Auas Mountains', Dinteria, 30: 41-92.

Chytrý, M., Tichý, L., Holt, J., \& Botta- Dukat, Z., 2002, 'Determination of diagnostic species with statistic fidelity measures', Journal of Vegetation Science, 13: 79-90, 10.1111/j.1654-1103.2002.tb02025.x.

Clark, V.R., Barker, N.P. \& Mucina, L., 2011, 'The Great Escarpment of southern Africa: a new frontier for biodiversity exploration', Biodiversity and Conservation, 20(12): 2543-2561, 10.1007/s10531-011-0103-3.

Craven, P. \& Vorster, P., 2006, 'Patterns of plant diversity and endemism in Namibia. Bothalia, 36(2): 175-189.

Edwards, D., 1983, 'A broad-scale structural classification of vegetation for practical purposes', Bothalia, 14 (3 \& 4): 705-712.
FAO, 1993, Global and national soils and terrain digital databases (SOTER). Procedures manual, Rome: Land and Water Development Division, Food and Agriculture Organisation of the United Nations.

Geological Survey, 1980, South West Africa / Namibia: Geological Map 1:1 000 000, Windhoek: Geological Survey of SWA/Namibia.

Giess, W., 1962, 'Some Notes on the Vegetation of the Namib Desert with a List of Plants Collected in the area visited by the Cape-Transvaal Museum Expedition during May 1959', Cimbebasia, 2, 1-35.

Giess, W., 1998. 'A Preliminary Vegetation Map of Namibia. Dinteria', 4, 1-112.

Gillet, F. and Julve, P., 2018. 'The integrated synusial approach to vegetation classification and analysis' Phytocoenologia, 48(2): 141-152, 10.1127/phyto/2017/0164.

Goudie, A. \& Viles, H.A., 2014, Landscapes and landforms of Namibia, Dordrecht: Springer.

Heltshe, J.F. \& Forrester, N.E., 1983, 'Estimating species richness using the Jackknife procedure', Biometrics, 39 (1), $1-11,10.2307 / 2530802$.

Hofmeyr, W., ed., 2004, Proceedings of the Important Plant Areas Workshop, Windhoek: National Botanical Research Institute.

Jarvis, A., Reuter, H.I., Nelson, A. \& Guevara, E., 2008, SRTM 90m Digital Elevation Database v4.1 [online], CGIAR-CSI, Available from: http://srtm.csi.cgiar.org/.

Jürgens, N., Haarmeyer, D.H., Luther-Mosebach, J., Dengler, J., Finckh, M. \& Schmiedel, U., eds., 2010. Patterns at Local Scale: The BIOTA Observatories. Göttingen \& Windhoek: Klaus Hess Publishers.

Jürgens, N., Oldeland, J., Hachfeld, B., Erb, E., \& Schultz, C., 2013, 'Ecology and spatial patterns of large-scale vegetation units within the central Namib Desert', Journal of Arid Environments, 93: 59-79, 10.1016/j.jaridenv.2012.09.009.

Kellner, K., 1986, 'n Plantekologiese studie van die Daan Viljoen-Wildtuin en gedeeltes van die plase Claratal en Neudam in die Hooglandsavanna, SWA, M.Sc. thesis, 
Potchefstroom Universiteit vir Christelike Hoër Onderwys, Potchefstroom.

King, L.C., 1963, South African Scenery, 3rd ed, New York: Hafner Publishing Company.

Klaassen, E.S. \& Kwembeya, E.G., eds., 2013, A checklist of Namibian indigenous and naturalised plants, Windhoek: National Botanical Research Institute.

Köppen, W., 1936, Das Geographische System der Klimate, Berlin: Bornträger Verlag.

Küchler, A.W. \& Zonneveld, I.S., 1988, Vegetation Mapping, Dordrecht: Kluwer Academic Publishers.

Kyalangalilwa, B., Boatwright, J.S., Daru, B.H., Maurin, O. \& van der Bank, M., 2013, 'Phylogenetic position and revised classification of Acacia s.I. (Fabaceae: Mimosoideae) in Africa, including new combinations in Vachellia and Senegalia', Botanical Journal of the Linnean Society, 172(4): 500-523, 10.1111/boj.12047.

Loots, S., 2005, Red Data Book of Namibian Plants, Pretoria and Windhoek: SABONET.

Luther-Mosebach, J., Dengler, J., Schmiedel, U., Röwer, I.U., Labitzky, T. \& Gröngröft, A., 2012, 'A first formal classification of the Hardeveld vegetation in Namaqualand, South Africa', Applied Vegetation Science, 15(3), 401-431, 10.1111/j.1654-109X.2011.01173.x.

Mendelsohn, J., Jarvis, A., Roberts, C. \& Robertson, T., 2002, Atlas of Namibia, Cape Town: David Phillips Publishers.

Mucina, L. \& Rutherford, M.C., eds., 2006, The Vegetation of South Africa, Lesotho and Swaziland, Pretoria: South African National Biodiversity Institute.

Müller, M.A.N., Herman, P.P.J. \& Kolberg, H.H., 2001, 'Flora of Southern Africa. Volume 33: Asteraceae, Part 4: Anthemideae, Fascicle 1: Eriocephalus and Lasiospermum', Flora of Southern Africa. Volume 33: Asteraceae, Part 4: Anthemideae, Fascicle 1: Eriocephalus and Lasiospermum.

NARIS, 2001, Namibian Agricultural Resources Information System (NARIS), Windhoek: Agro-Ecological Zoning Program, Ministry of Agriculture, Water and Rural Development.

Njenga, E.W., 2005, The chemotaxonomy, phylogeny and biological activity of the genus Eriocephalus L. (Asteraceae), $\mathrm{PhD}$ dissertation, University of the Witwatersrand, Johannesburg.

Nordenstam, B., 1966, 'Euryops in South West Africa', Botaniska Notiser, 119(4): 475-533.

Palmer, M.W., 1990, 'The estimation of species richness by extrapolation', Ecology, 71 (3), 1195-1198, $10.2307 / 1937387$

Roleček, J., Tichý, L., Zelený, D. \& Chytrý, M., 2009, 'Modified TWINSPAN classification in which the hierarchy respects cluster heterogeneity', Journal of Vegetation Science, 20: 596-602, 10.1111/j.1654-1103.2009.01062.x.

SASSCAL, 2020, SASSCAL WeatherNet - Welcome to the weather stations of Angola, Botswana, Namibia and Zambia [online], SASSCAL WeatherNet - Welcome to the weather stations of Angola, Botswana, Namibia and Zambia, Available from: http://www.sasscalweathernet.org/index.php [Accessed 29 May 2020].

Schalk, K.E.L., 1983, 'Geologische Geschichte des Gamsberggebietes', Journal der SWA Wissenschaftliche Gesellschaft, 38: 7-15.
Schneider, G., 2004, The Roadside Geology of Namibia, Berlin, Stuttgart: Gebrüder Borntraeger.

South African Committee for Stratigraphy, 1980, Stratigraphy of South Africa Part 1: Lithostratigraphy of the Republic of South Africa, South West Africa/Namibia, and the Republics of Bophutatswana, Transkei and Venda, Pretoria: Dept. of Mineral and Energy Affairs.

Strohbach, B.J., 2001, 'Vegetation survey of Namibia', Journal of the Namibia Scientific Society, 49: 93-124.

Strohbach, B.J., 2008, 'Mapping the major catchments of Namibia', Agricola, 18: 63-73.

Strohbach, B.J., 2017, 'Vegetation of the Auas-Oanob Conservancy in the Khomas Hochland of Namibia', Namibian Journal of Environment, 1(A): 19-42.

Strohbach, B.J., 2018, 'Making more of vegetation classification results: A Livestock Farming Suitability Index as tool for Land-Use Planning in Namibia', Phytocoenologia, 48(1), 7-22, 10.1127/phyto/2017/0182.

Strohbach, B.J., 2019, 'Vegetation of the Thornbush Savanna of central Namibia: Baseline description of the present vegetation at Farm Erichsfelde, Otjizondjupa Region', Namibia Journal of Environment, 3(A): 17-36.

Strohbach, B.J., Adank, W.F., Coetzee, M.E. \& Jankowitz, W.J., 2019, 'A baseline description of the vegetation and soils of Farm Klein Boesman, Khomas Region, Namibia', Namibian Journal of Environment, 3(A): 37-55.

Strohbach, B.J. \& Kangombe, F., 2012, 'National Phytosociological Database of Namibia', Biodiversity \& Ecology, 4: 298, 10.7809/b-e.00095

Swart, R. \& Marais, C., 2009, Landshapes: the geomorphology of Namibia, Windhoek, Namibia: Macmillan Education Namibia Publishers.

Theron, G.K., van Rooyen, N. \& van Rooyen, M.W., 1980 'Vegetation of the lower Kuiseb River', Madoqua, 11(4): 327-345.

Tichý, L. \& Chytrý, M., 2006, 'Statistical determination of diagnostic species for site groups of unequal size', Journal of Vegetation Science, 17: 809-818, 10.1111/j.16541103.2006.tb02504.x.

Volk, O.H. \& Leippert, H., 1971, 'Vegetationsverhältnisse im Windhoeker Bergland, Südwestafrika', Journal der SWA Wissenschaftliche Gesellschaft, XXV, 5-44.

Walter, H., Harnickell, E. \& Mueller-Dombois, D., 1975, Climate-diagram maps of the individual continents and the ecological climatic regions of the earth, Berlin: Springer Verlag.

Ward, J.D., 1987, The Cenozoic succession in the Kuiseb valley, central Namib Desert, Windhoek: Geological Survey, Department of Economic Affairs.

Weber, H.E., Moravec, J. \& Theurillat, J.P., 2000, 'International Code of Phytosociological Nomenclature, 3rd edition', Journal of Vegetation Science, 11: 739-768, $10.2307 / 3236580$.

Winterbach, R., Bredenkamp, G.J., Deutschländer, M.S. \& Mucina, L., 2000, 'Preliminary syntaxonomic scheme of vegetation classes for the Central Bushveld of South Africa', Proceedings IAVS Symposium, 123-127.

Wittig, R., 1976, 'Die Gamsberg-Spalten (SW-Afrika) -Zeugen Karroo-zeitlicher Erdbeben',Geologische Rundschau, 65(1), 1019-1034. 


\section{Appendix 1}

Synoptic table for the Pre-Namib and Escarpment Zone communities, with fidelity (phi coeff.) and frequncy of occurence (\%)

Available online only DOI: http://dx.doi.org/10.38201/btha.abc.v51.i2.s4a.

\section{Appendix 2}

Phytosociological Table

Available online only DOI: http://dx.doi.org/10.38201/btha.abc.v51.i2.s4b. 